\title{
Brachiopods from the Valdeteja Formation (Pennsylvanian; Cantabrian Mountains, NW Spain)
}

\author{
María Luisa Martínez Chacón, Oviedo and Cor F. Winkler Prins, Leiden
}

With 6 figures and 4 tables

\begin{abstract}
Martínez Chacón, M. L. \& Winkler Prins, C. F. (2009): Brachiopods from the Valdeteja Formation (Pennsylvanian; Cantabrian Mountains, NW Spain). - N. Jb. Geol. Paläont. Abh., 252: 91-111; Stuttgart.
\end{abstract}

\begin{abstract}
After a short introduction on the lower Pennsylvanian (Bashkirian to lowermost Moscovian) Valdeteja Formation in its stratigraphical context, an overview of its brachiopod faunas is presented and their palaeoecological and palaeogeographic importance discussed. Two new genera of the Strophalosiidina, showing adaptations to a reef environment, are described. The genus Ovetina (type species $O$. truyolsi gen. et sp. nov.) is an aulostegid with a well developed ventral flange. Miroproductus (type species M. posadai gen. et sp. nov.) is an early richthofenioid, probably derived from an aulostegid such as Institina MuIR-WoOD \& COOPER, 1960.
\end{abstract}

Key words: Brachiopods, Strophalosiidina, Valdeteja Formation, palaeoecology, upper Bashkirian, Cantabrian Mountains, Spain.

\section{Introduction}

The Valdeteja Formation was originally described by WinkLER PRINS (1968) as the Valdeteja Member of the Escapa Formation and later elevated to the rank of formation by WAGNER et al. (1971). It forms the upper part of what used to be known as the "caliza de montaña" (e.g., EzQUERRA DEL BAYO 1844) or "calcaires des cañons" (e.g., BARROIS 1882), the former being a direct translation of the British Mountain Limestone which is of an older, Mississippian, age.

The Valdeteja Formation consists mainly of light gray, massively bedded limestone, often bioclastic, with some marly beds (EICHMÜLLER 1985). The formation is locally rich in macrofaunas, especially brachiopods (WINKLER PRINS 1971). It varies considerably in thickness: from a few metres to some $800 \mathrm{~m}$ and crops out in steeply dipping thrust slices over a large part of the Asturo-Leonese realm, especially in the Sobia-Bodón, Aramo, Picos de Europa and Sierra del Brezo areas (Fig. 1), as well as in the Revilla Nappe in northern Palencia (see WAgNER \& Winkler Prins 2000). The Valdeteja Formation (Fig. 2) has been dated, mainly on fusulinids, as Bashkirian-lower Moscovian (VILla 1982; VILla et al. 2001).

Underlying the Valdeteja Formation is the Barcaliente Formation (originally described as the Vegacervera Member; see WAGNER et al. 1971), consisting of black, fetid, laminated limestone which is poor in fossils. Occasional conodonts indicate an early Bashkirian age for its upper part, the lower part clearly being of Serpukhovian age (MÉNDEZ \& MENÉNDEZ Álvarez 1985, SANZ-LóPez et al. 2006). The uppermost part of the Barcaliente Formation is characterised by collapse breccias with blocks up to cubic 


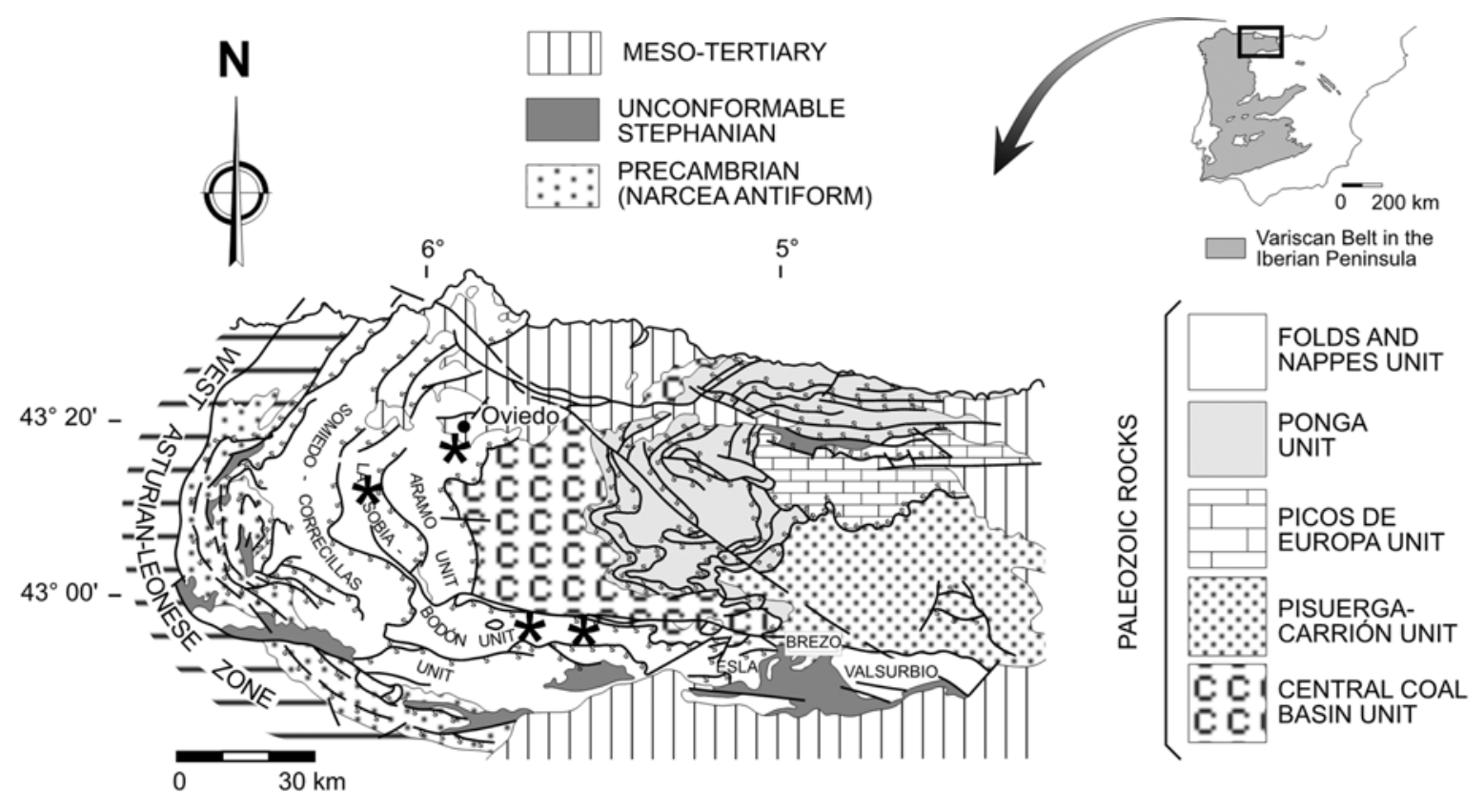

Fig. 1. Geological map showing the main geological structures (after PÉREZ-Estaún et al. 1988), and the principal faunal localities of the Valdeteja Formation (asterisks). From W to E: Entrago, Latores, Cármenes and Valdeteja.

metre size, the Porma Breccia of Reuther (1977), as can be clearly seen in the Barcaliente type section (WINKLER PRINS 1971: pl. 1, fig. 2).

The carbonate platform of the Valdeteja Formation formed an external rim around a basin, where the mud sedimentation did not keep up with subsidence (the Ricacabiello Formation, see MARTínEZ CHACón et al. 1985). Overlying and partly replacing the Valdeteja Formation is the San Emiliano Formation (Fig. 2) of BROUWER \& VAN GINKEL (1964), a succession of mudstone with intercalated limestones and sandstones (see also Bowman 1982, 1985; CARBALleIRA et al. 1985; FERNÁNDEZ 1993; VAN GinKel \& Villa 1996).

\section{Faunas and floras}

After the (semi-)pelagic faunas of the Mississippian (e.g. Martínez Chacón \& Winkler Prins 1993; Amler \& Winkler Prins, 1999; SÁnchez de Posada et al. 2001), the Pennsylvanian starts with rich benthic faunas of the Valdeteja Formation. Most fossil groups are represented, but many have only been poorly studied (see Table 1) and some are rare, such as the cephalopods (mainly orthocones), rostroconchs, porifera, trilobites and identifiable echinoderms (crinoid ossicles are locally abundant). By far the most com- mon and best studied fossils are the brachiopods, but these too are in need of a revision. The brachiopod study started with the locality of Latores (see Martínez Chacón \& Winkler Prins 2007, 2008) and is continued and extended to other areas by us (Martínez Chacón \& Winkler Prins 2006).

\section{Comments on the brachiopod faunas}

The study of the fossils, and particularly the brachiopods, is hampered by their occurrence in massive and re-crystallised limestone, making extraction of the fossils extremely difficult. The shells are often decorticated and the internal structures can usually only be observed in the apical parts (see MARTínEZ Chacón \& Winkler Prins 2006). Although isolated specimens are not uncommon, only levels with rich faunas (forming lenticles), such as those at Latores (Delépine \& Llopis Llado 1956; Martínez Chacón 1979; Martínez Chacón \& Winkler Prins 2007), Cármenes and Valdeteja (WINKLER PrINS 1968, 1971), proved useful for a detailed study, since one needs a sufficient number of specimens for identification of the taxa present. Even so, identifications are often insecure and the material proved sometimes insufficient to describe a new species or genus. The 


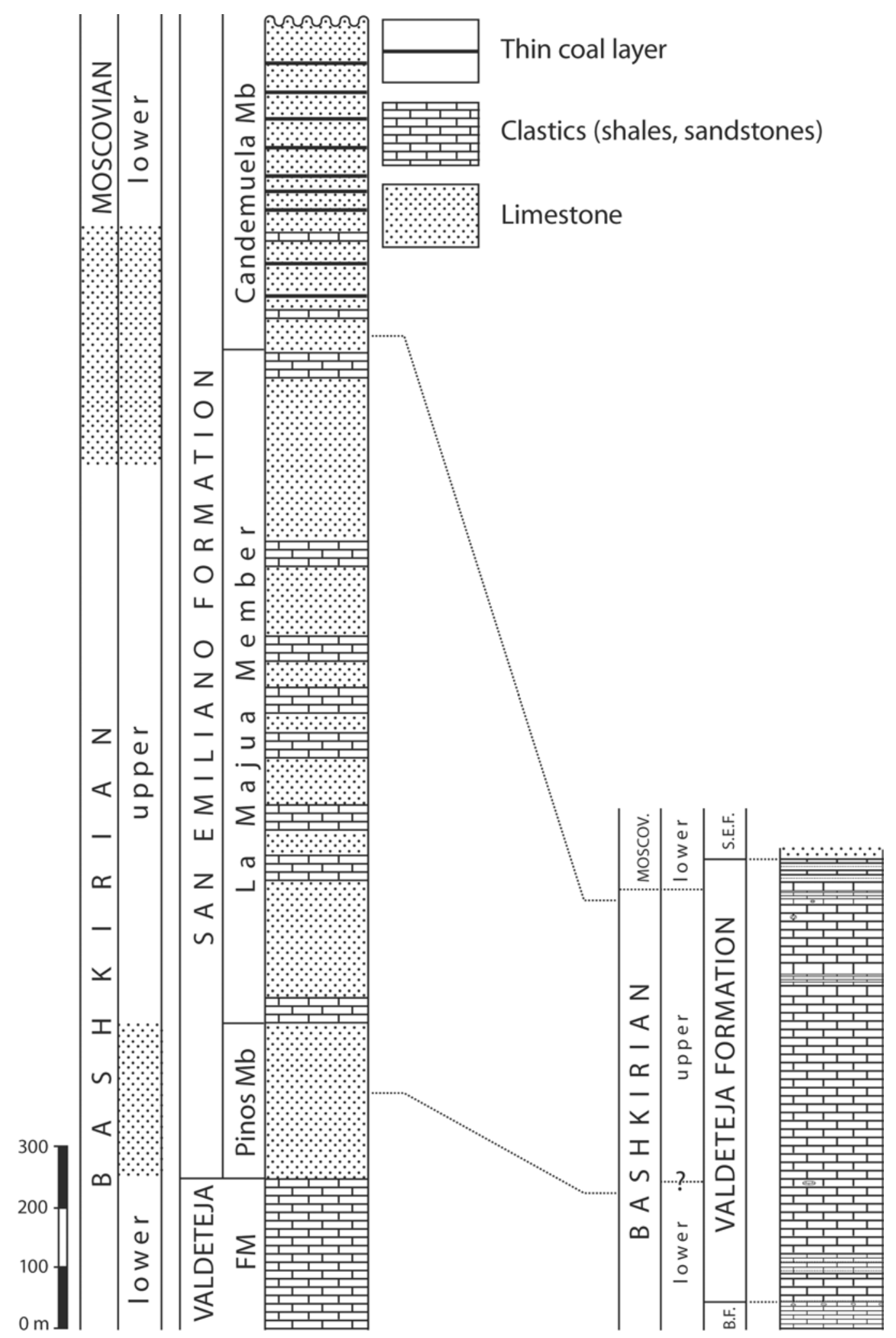

Fig. 2. Stratigraphic columns of the type sections of the San Emiliano Formation (after van Ginkel \& ViLLA 1996: Fig. 3) and the Valdeteja Formation (after VILLA et al. 2001: fig. 2). B.F. = Barcaliente Formation; S.E.F. = San Emiliano Formation. 
Table 1. List of fossil groups occurring in the Valdeteja Formation and authors who studied them.

Algae, Cyanobacteria and Problematica: RÁCZ (1964), RÁCZ \& GERMS in WINKLER PRINS (1968), EICHMÜLLER (1985).

Fusulinidae: VILLA (1982, 1989, 1995), EICHMÜLLER (1985), VILLA et al. (2001).

Conodonts: Truyols et al. (1984), MÉNDEZ \& MENÉNDEZ ÁlVAREZ (1985), VAN DEN

BOOGAARD \& BLESS (1985).

Ostracoda: Bless \& SÁnchez de Posada (1973), SÁnchez de Posada (1976), Becker (1982).

Trilobita: GANDL, in MARTínez CiIACÓN (1979), GANDL (1987).

Porifera: GARCÍA-BELLIDO CAPDEVILA (2002).

Anthozoa: De Groot, in WAgner (1963), DE GROOT, in WINKLER PRINS $(1968,1971)$, RODRIGUUZZ (1984), BOLL (1985), EICHMÜLLER (1985).

Crinoidea, Echinoidea: not yet studied.

Cephalopoda: WAgner Gentis, in MARTínez CHACón (1979). *)

Bivalvia: DELÉPINE \& LLOPIS LLADO (1956).

Gastropoda: DELÉPINE \& LLOPIS LLADO (1956).

Rostroconcha: BABIN et al. (1999).

Bryozoa: ERNST \& WINKLER PRINS (2006, 2008).

Brachiopoda: DelÉPINE (1943), DELÉPINE \& LLOPIS LLADO (1956), WiNKLER PRINS (1968, 1971, 2007), TrUyols et al. (1984), WinkLER Prins, in EICHMÜLlER (1985), MARTínez CHACÓN (1977a, 1977b, 1979), MARTínez CHACÓN \& WinkLER PRINS (2006, 2007, 2008).

*) The specimen from Cármenes identified by WAGNER-GENTIS (in MOORE et al. 1971, pl. 6) as Branneroceras branneri and now considered to be a Diaboloceras? sp. (J. KULLMANN, pers. comm. 2.8.2006) comes from deposits lying disconformably (with a palaeokarst) upon the Valdeteja Formation, as one of us (C.F.W.P.) found out in July 2006.

richest levels are in the upper part of the formation of late Bashkirian to possibly earliest Moscovian age: Latores (the richest and most varied fauna) and Entrago in Asturias, and Valdeteja (with a succession of fossil horizons of different composition; see WinKLER PRINs 1971) and Cármenes in León; a fauna from San Emiliano is somewhat older, of early Bashkirian age (VAN GinKel \& VILLA 1996).

The rich and varied brachiopod faunas of the Valdeteja Formation are summarised in Table 2. The general aspect of the fauna as a whole is rather similar to that of the Viséan limestone faunas from northern Europe (Kohlenkalk, Mountain Limestone; see WolfENDEN 1958; BRUNTON 1984), although on closer inspection many forms proved different (cf. Martínez Chacón \& Winkler Prins 2007: table 1), corroborating the younger (essentially Bashkirian) age suggested by WINKLER PRINS (1968) and proven on fusulinids (see VILLA et al. 2001). The close resemblance with the brachiopod fauna from the Hare Fiord Formation (Ellesmere Island, Arctic Canada; see CARTer \& Poletaev 1998) supports the age identification, as do the Bashkirian elements known from the Donnbass (see Table 3). The large number of productides is remarkable, although well known for the Carboniferous-Permian seas, called "Productus" seas by SARYtcheva \& Sokolskaya (1959, 1960: 350). It will be no surprise that there is a great affinity of the brachiopod faunas of the Valdeteja Formation with those from the Cuera Limestones (28 genera in common, Table 3; see MARTínez CHACóN \& BAHAMONDE 2008), given the reefoid character of 
Table 2. List of brachiopod species found in the Valdeteja Formation listed by locality.

\begin{tabular}{|c|c|c|c|c|}
\hline Brachiopoda & Latores & Entrago & Valdeteja & Cármenes \\
\hline Caenanoplia? sp. & $\mathrm{X}$ & & & $\mathrm{X}$ \\
\hline Rugosochonetes sp. & $\mathrm{X}$ & $x$ & & \\
\hline Plicochonetes? sp. & $x$ & & & $\mathrm{X}$ \\
\hline Productina pectinoides (Phillips, 1836) & $\mathrm{X}$ & & & \\
\hline Alitaria frechi (Paeckelmann, 1931) & $\mathrm{X}$ & & $\mathrm{X}$ & \\
\hline Rugivestis? sp. & $x$ & & & $x$ \\
\hline Quasiavonia cf. aculeata (Sowerby, 1814) & $\mathrm{X}$ & & $\mathrm{X}$ & \\
\hline Krotovia granulosa (Phillips, 1836) & & & $\mathrm{X}$ & $\mathrm{x}$ \\
\hline Breileenia? sp. & $\mathrm{X}$ & $\mathrm{X}$ & $x$ & $\mathrm{X}$ \\
\hline Incisiidae gen. et sp. nov. & & & $\mathrm{x}$ & \\
\hline Limbifera? sp. nov. & $\mathrm{x}$ & & & \\
\hline Maemia archboldi Martínez Chacón \& Winkler Prins, 2008 & $x$ & $x$ & $x$ & $\mathrm{X}$ \\
\hline Duartea sp. & $\bar{x}$ & $x$ & $\mathrm{x}$ & \\
\hline Inflatia sp. & $\mathrm{X}$ & & $\mathrm{x}$ & \\
\hline Productus carbonarius de Koninck, 1842 & & & $\mathrm{x}$ & \\
\hline Productus concinnus Sowerby, 1821 & $\mathrm{x}$ & $x$ & $\mathrm{X}$ & $\mathrm{X}$ \\
\hline Hystriculina sp. & $x$ & $\mathrm{X}$ & $\mathrm{X}$ & $\mathrm{X}$ \\
\hline Eomarginifera praecursor (Muir-Wood, 1928) & $\mathrm{X}$ & $\mathrm{X}$ & $\mathrm{X}$ & $\mathrm{X}$ \\
\hline Alexenia? sp. & $\mathrm{X}$ & $\mathrm{X}$ & $\mathrm{X}$ & \\
\hline Pugilis? sp. & $\mathrm{X}$ & & & \\
\hline Bicarteria? sp. & $\mathrm{x}$ & & $\mathrm{X}$ & $\mathrm{X}$ \\
\hline Latispinifera cf. chaykensis Lazarev, 2000 & $\mathrm{X}$ & & $\mathrm{x}$ & \\
\hline Latispinifera aff. ivanovi (Lapina, 1957) & $\mathrm{X}$ & $\mathrm{X}$ & $\mathrm{x}$ & $\mathrm{X}$ \\
\hline Admoskovia cf. aljutovensis Lazarev, 2000 & & $\mathrm{X}$ & & \\
\hline Buxtonia? sp. & $x$ & & & \\
\hline Kochiproductus? sp. & $\mathrm{X}$ & & & $\mathrm{X}$ \\
\hline Echinaria cf. knighti (Dunbar \& Condra, 1932) & $\mathrm{X}$ & $\mathrm{X}$ & $\mathrm{X}$ & \\
\hline Echinoconchella? elegans (M'Coy, 1844) & $\mathrm{x}$ & $x$ & $\mathrm{x}$ & $\mathrm{X}$ \\
\hline Echinoconchella? venusta (Thomas, 1914) & $x$ & & & \\
\hline Pustula? sp. & & & $\mathrm{X}$ & \\
\hline Balakhonia? continentalis (Tornquist, 1895) & & & $\mathrm{X}$ & $\mathrm{X}$ \\
\hline Fluctuaria undata (Defrance, 1826) & & $\mathrm{x}$ & & $\mathrm{X}$ \\
\hline Fluctuaria sp. & $\mathrm{X}$ & & $\mathrm{X}$ & \\
\hline Marginovatia? sp. & $\mathrm{x}$ & $\mathrm{x}$ & $\mathrm{X}$ & $\mathrm{X}$ \\
\hline Liraria? sp. & $\mathrm{x}$ & & & \\
\hline Ovatia cf. Jaevicosta (White, 1861) & $\mathrm{X}$ & $\mathrm{X}$ & $\mathrm{X}$ & \\
\hline Plicatiferina sinecosta (Martínez Chacón, 1979) & $\mathrm{x}$ & & $\mathrm{x}$ & $\mathrm{x}$ \\
\hline Miroproductus posadai gen. et sp. nov. & $\bar{x}$ & $x$ & & \\
\hline Retroplexus? sp. & $\mathrm{X}$ & & & \\
\hline Ovetina truyolsi gen. et sp. nov. & $\mathrm{x}$ & & & \\
\hline Meekella sp. & $\mathrm{x}$ & $\mathrm{X}$ & $\mathrm{X}$ & \\
\hline Meekella? ex gr. gigantea Stuckenberg, 1905 & $\mathrm{X}$ & $x$ & & \\
\hline Schuchertella sp. & $\mathrm{X}$ & & $\mathrm{x}$ & \\
\hline Streptorhynchus? cf. subpelargonatus sensu Demanet, 1934 & $\mathrm{x}$ & & & \\
\hline Rhipidomela michelini (Léveillé, 1835) & $\mathrm{X}$ & & $\mathrm{X}$ & $X$ \\
\hline Orthotichia? sp. & $x$ & $\mathrm{x}$ & & $\mathrm{X}$ \\
\hline Pugnax aff. acuminatus (Sowerby, 1822) & $x$ & & & $\mathrm{X}$ \\
\hline Pugnoides rosae Martínez Chacón, 1979 & & $\mathrm{X}$ & & \\
\hline Callaiapsida alcaldei (Martinez Chacón, 1977) & $\mathrm{X}$ & $\mathrm{x}$ & & $X$ \\
\hline Psilocamara sp. & $\mathrm{x}$ & & & \\
\hline Lambdarina? sp. & & & $x$ & \\
\hline Rhynchopora nikitini (Tschernyschew, 1885) & $x$ & & & \\
\hline Rhynchopora sp. & $\mathrm{x}$ & & & \\
\hline Trasgu minor Martínez Chacón, 1979 & $\mathrm{x}$ & $\mathrm{X}$ & & \\
\hline Yanishewskiella globosa Martínez Chacón, 1979 & & $\mathrm{x}$ & $X$ & \\
\hline
\end{tabular}


Table 2 cont.

\begin{tabular}{|c|c|c|c|c|}
\hline Rhynchonellida indet. A & $\mathrm{X}$ & & & \\
\hline Rhynchonellida indet. B & $\bar{X}$ & & & \\
\hline Cleiothyridina sp. & $x$ & $\mathrm{X}$ & & \\
\hline Cardiothyris sp. nov. & & $x$ & & \\
\hline Athyrididina indet. & $\mathrm{X}$ & $X$ & & \\
\hline Hustedia sp. & $x$ & & & \\
\hline Crurithyris cf. urei (Fleming, 1828) & $x$ & $x$ & $\mathrm{X}$ & $X$ \\
\hline Tiramnia aff. walteri Carter \& Poletaev, 1998 & $x$ & $\mathrm{X}$ & & $x$ \\
\hline Donispinifer? sp. & & $\mathrm{X}$ & & \\
\hline Anthracospirifer cf. solenensis Poletaev, 2001 & $\mathrm{X}$ & $\mathrm{X}$ & & \\
\hline Anthracothyrina? sp. & $\mathrm{X}$ & & $\mathrm{X}$ & $\mathrm{X}$ \\
\hline Alphachoristites (Prochoristites)? sp. & $\mathrm{X}$ & & $\mathrm{X}$ & \\
\hline Parachoristites sp. & $\mathrm{X}$ & & & \\
\hline Gypospirifer sp. & $\mathrm{X}$ & & & \\
\hline "Neospirifer" ex gr. dunbari King, 1933 & & $\mathrm{X}$ & $\mathrm{X}$ & $\mathrm{x}$ \\
\hline Cantabriella sp. & $\mathrm{x}$ & & & $\mathrm{x}$ \\
\hline Brachythyris? sp. & $\mathrm{X}$ & & & \\
\hline Meristorygma sp. & $\mathrm{X}$ & & $\mathrm{X}$ & \\
\hline Kitakamithyris? sp. & $x$ & & & \\
\hline Phricodothyris ovata (Chao, 1929) & $\mathrm{X}$ & $x$ & $\mathrm{X}$ & $\mathrm{x}$ \\
\hline Punctospirifer? sp. & $\mathrm{X}$ & & & \\
\hline Altiplecus sp. & & & & $\mathrm{x}$ \\
\hline Crenispirifer sp. & & $\mathrm{X}$ & $\mathrm{X}$ & \\
\hline Spiriferellinidae indet. & $\mathrm{X}$ & & & \\
\hline Girtyella llopisi Martínez Chacón \& Winkler Prins, 2008 & $\mathrm{X}$ & $\mathrm{x}$ & $?$ & $?$ \\
\hline Dielasmella? delepinei M. Ch. \& W. P., 2008 & $\mathrm{X}$ & $x$ & & $\mathrm{x}$ \\
\hline Gillediinae gen.et sp. nov. & & $x$ & & \\
\hline Terebratulida indet. A & & $x$ & & \\
\hline Terebratulida indet. B & & $\mathrm{x}$ & & \\
\hline 84 & 66 & 38 & 37 & 30 \\
\hline
\end{tabular}

these limestones and the fact that the brachiopods are from levels of the same age (late Bashkirian-early Moscovian). There is also a strong similarity with the brachiopods from the San Emiliano Formation (23 genera in common, Table 3), which however lack the specialised forms characteristic of a reefoid environment.

\section{Palaeoecological remarks}

The brachiopods of the Valdeteja Formation are characteristic of shallow water faunas of a well oxygenated, warm sea with wave action and in particular for the carbonate platforms with reefoid structures (we use "reefs" in the broad sense of FLÜGEL \& KIESSLING 2002: "laterally confined biogenic structures, developed by the growth or activity of sessile benthic organisms and exhibiting topographic relief and [inferred] rigidity.") in contrast to the Mississippian semi-pelagic "quiet-water" faunas (see for example Martínez Chacón \& Winkler Prins 1993; SÁnchez DE PosAda et al. 2001). The bottom was stable enough to support a varied fauna and flora. Many forms characteristic for a reefoid environment, similar to those from the Viséan (e.g., MUNDY \& BRUNTON 1986; Brunton \& Mundy 1986, 1988; BRUnTON et al. 1994) and Permian (GRANT 1971; CoOPER \& GRANT 1975) are found especially among the strophalosiidines. The productides of this suborder normally were fixed to the substrate by cementation of the ventral valve or by rhizoid spines.

Four strophalosiidine species are present in the Valdeteja Formation, belonging to different superfamilies of this suborder. The strophalosioid Plicatiferina sinecosta (MARTínEz CHACÓN, 1979) (Fig. 3.13.2 ) is one of the most abundant species from Latores, occurring also at Valdeteja and other localities in the Cantabrian Mountains of the same age. The genus is also known from the Pennsylvanian of the Urals and its prolongation, reaching into the Canadian Arctic. Two species, each represented only by a few specimens, were assigned to the aulostegoid subfamily Institellinae; both are considered typical of a reef community and are compared with species from the 
Table 3. List of brachiopod genera found in the Valdeteja Formation compared with other formations in the Cantabrian Mountains and with other areas in order to show their palaeogeographic distribution.

\begin{tabular}{|c|c|c|c|c|c|c|c|c|c|c|}
\hline genus & Valdeteja & Cuera & San Em & Hare Fi & Vis. NW $\mathrm{E}$ & Alps & Donnb & Urals & Spitsb & Texas $P$. \\
\hline Caenanoplia & $\mathrm{x}$ & & & & & & & & & \\
\hline Rugosochonetes & $\mathrm{X}$ & & $X$ & & $\mathrm{X}$ & $x$ & $x$ & $\bar{x}$ & & \\
\hline Plicochonetes & $x$ & & & & $\mathrm{X}$ & & & & & \\
\hline Productina & $\mathrm{x}$ & & & & $\mathrm{X}$ & & $x$ & $x$ & & \\
\hline Alitaria & $\mathrm{x}$ & $\mathrm{x}$ & $\mathrm{X}$ & & $\mathrm{X}$ & & & & & \\
\hline Rugivestis & $\mathrm{x}$ & & & $\mathrm{X}$ & & & 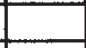 & $\bar{x}$ & & $\mathrm{X}$ \\
\hline Quasiavonia & $\mathrm{x}$ & & $x$ & & $\mathrm{x}$ & $\mathrm{x}$ & & & & \\
\hline Krotovia & $x$ & $\mathrm{X}$ & $\mathrm{X}$ & $\mathrm{X}$ & $\mathrm{X}$ & $\mathrm{X}$ & $\mathrm{X}$ & $x$ & $\mathrm{X}$ & \\
\hline Breileenia & $\mathrm{x}$ & & & & $\mathrm{x}$ & & $x$ & & & \\
\hline Incisiinae gen, nov. & $\mathrm{X}$ & & $\mathrm{X}$ & & & & $x$ & & & \\
\hline Limbifera & $x$ & $\mathrm{X}$ & & & $\mathrm{X}$ & & 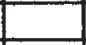 & & & \\
\hline Maemia & $\mathrm{X}$ & $\mathrm{X}$ & & $\mathrm{X}$ & & & E & $x$ & & \\
\hline Duartea & $\mathrm{X}$ & & 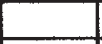 & & & & & $x$ & $x$ & \\
\hline Admoskovia & $x$ & $\mathrm{X}$ & & & & & $\mathrm{X}$ & & & \\
\hline Bicarteria & $x$ & $\mathrm{x}$ & $x$ & & & & & & $\mathrm{X}$ & \\
\hline Latispinifera & $\mathrm{X}$ & & $\mathrm{x}$ & & & & 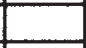 & & $\mathrm{X}$ & \\
\hline Inflatia & $\mathrm{X}$ & $\mathrm{X}$ & & & $\mathrm{x}$ & & - & & & \\
\hline Productus & $\mathrm{x}$ & & $x$ & & $\mathrm{x}$ & & $\mathrm{x}$ & $\mathrm{x}$ & & \\
\hline Hystriculina & $x$ & $\mathrm{X}$ & $\mathrm{X}$ & $x$ & & $x$ & $\mathrm{X}$ & $\mathrm{X}$ & $\mathrm{x}$ & $\mathrm{X}$ \\
\hline Eomarginifera & $\mathrm{X}$ & & $\mathrm{X}$ & $X$ & $\mathrm{x}$ & & & 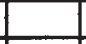 & & \\
\hline Alexenia & $x$ & $x$ & & & & $x$ & & $\mathrm{x}$ & & \\
\hline Pugilis & $x$ & & & & $\mathrm{X}$ & & & & & \\
\hline Buxtonia & $x$ & & & & $\mathrm{X}$ & & $\mathrm{X}$ & $x$ & $\mathrm{X}$ & \\
\hline Kochiproductus & $\mathrm{x}$ & 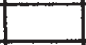 & & 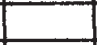 & $x$ & & & $\mathrm{x}$ & & $\mathrm{X}$ \\
\hline Echinaria & $\mathrm{X}$ & $\mathrm{X}$ & & $\mathrm{x}$ & & & & $\mathrm{X}$ & $x$ & $\mathrm{X}$ \\
\hline Echinoconchella & $\mathrm{X}$ & & & & $\mathrm{X}$ & & & & $\mathrm{X}$ & \\
\hline Pustula & $\mathrm{x}$ & & & & $\mathrm{X}$ & & $x$ & & & \\
\hline Fluctuaria & $\mathrm{x}$ & $x$ & & $\mathrm{x}$ & $\mathrm{x}$ & & $x$ & $\mathrm{x}$ & & \\
\hline Marginovatia & $x$ & & & & & & & & & \\
\hline Ovatia & $\mathrm{X}$ & & $x$ & & $\mathrm{X}$ & & & $x$ & $\mathrm{X}$ & \\
\hline Balakhonia & $x$ & & & & & & & $x$ & & \\
\hline Liraria & $\mathrm{x}$ & $\mathrm{X}$ & & $x$ & & & & & & $\mathrm{x}$ \\
\hline Plicatiferina & $\mathrm{x}$ & $\mathrm{x}$ & $\mathrm{X}$ & $\mathrm{x}$ & & & & $x$ & & \\
\hline Retroplexus & $x$ & & & & $\mathrm{x}$ & & & & & \\
\hline Ovetina & $x$ & & & & & & & & & \\
\hline Miroproductus & $x$ & & & & & & & & & \\
\hline Meekella & $\mathrm{x}$ & & E & & & & & $\mathrm{X}$ & $\mathrm{X}$ & \\
\hline Schuchertella & $\mathrm{x}$ & $\mathrm{x}$ & 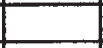 & & $x$ & & $x$ & & & $\mathrm{x}$ \\
\hline Streptorhynchus & $x$ & & & & $\mathrm{X}$ & $\mathrm{X}$ & & $\mathrm{x}$ & $\mathrm{X}$ & $x$ \\
\hline Rhipidomella & $x$ & $\mathrm{X}$ & $\mathrm{x}$ & $x$ & $\mathrm{x}$ & $\mathrm{x}$ & & $\mathrm{x}$ & $\mathrm{X}$ & $\mathrm{x}$ \\
\hline Orthotichia & $\mathrm{x}$ & $\mathrm{X}$ & $\mathrm{x}$ & $\mathrm{x}$ & & & & $\mathrm{X}$ & $\mathrm{X}$ & $\mathrm{X}$ \\
\hline Pugnax & $\mathrm{x}$ & $x$ & 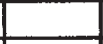 & & $\mathrm{X}$ & & $x$ & & & \\
\hline \begin{tabular}{|l} 
Pugnoides \\
\end{tabular} & $\mathrm{X}$ & & & & & & & & & \\
\hline Callaiapsida & $x$ & $x$ & $\mathrm{X}$ & & & & & $x$ & $x$ & \\
\hline Psilocamara & $x$ & & & & & & & & & $x$ \\
\hline Yanishewskiella & $x$ & & & & & $x$ & & $x$ & & \\
\hline Lambdarina & $x$ & & & & $\mathrm{x}$ & & & & & \\
\hline Rhynchopora & $\mathrm{x}$ & $x$ & & $\mathrm{X}$ & & $\mathrm{x}$ & & $\mathrm{x}$ & $\mathrm{X}$ & $\mathrm{X}$ \\
\hline Trasgu & $\mathrm{x}$ & & & & & & & & & \\
\hline Cleiothyridina & $\mathrm{x}$ & $\mathrm{x}$ & $x$ & & $\mathrm{x}$ & $x$ & $\mathrm{x}$ & $\mathrm{X}$ & $\mathrm{X}$ & $\mathrm{X}$ \\
\hline Cardiothyris & $\mathrm{x}$ & & & & & & & & & \\
\hline Hustedia & $x$ & $\mathrm{X}$ & $\mathrm{x}$ & $\mathrm{x}$ & $x$ & $\mathrm{X}$ & & $\mathrm{x}$ & $\mathrm{x}$ & $\mathrm{X}$ \\
\hline Crurithyris & $\mathrm{x}$ & $\mathrm{x}$ & $x$ & $\mathrm{X}$ & $\mathrm{x}$ & $x$ & & $\mathrm{X}$ & $\mathrm{X}$ & $\mathrm{X}$ \\
\hline Tiramnia & $x$ & $\mathrm{X}$ & $\mathrm{x}$ & $\mathrm{X}$ & & & & $\mathrm{X}$ & & \\
\hline Donispirifer & $x$ & $\mathrm{x}$ & & $\mathrm{x}$ & & & $\mathrm{X}$ & $x$ & & \\
\hline
\end{tabular}


Table 3 cont.

\begin{tabular}{|c|c|c|c|c|c|c|c|c|c|c|}
\hline Anthracospirifer & $X$ & $\mathrm{X}$ & $\mathrm{X}$ & $\mathrm{X}$ & & $x$ & $\mathrm{X}$ & & & \\
\hline Anthracothyrina & $\mathrm{x}$ & $\mathrm{X}$ & $\mathrm{X}$ & $x$ & $x$ & & $\mathrm{X}$ & & & \\
\hline Alphachoristites (Prochoristites) & $\mathrm{x}$ & $\mathrm{X}$ & $\mathrm{X}$ & & & & $\mathrm{X}$ & $\mathrm{X}$ & & \\
\hline Parachoristites & $\mathrm{x}$ & $\mathrm{x}$ & $x$ & $\mathrm{x}$ & & & $\mathrm{X}$ & $\mathrm{X}$ & & \\
\hline "Neospirifer" & $\mathrm{x}$ & & $\mathrm{X}$ & & & $x$ & $\mathrm{x}$ & $x$ & & \\
\hline Gypospirifer & $\mathrm{X}$ & $\mathrm{X}$ & & $x$ & & & & & & \\
\hline Cantabriella & $\mathrm{X}$ & $\mathrm{X}$ & $\mathrm{X}$ & $\mathrm{x}$ & & $\mathrm{x}$ & & & & \\
\hline Brachythyris & $x$ & $x$ & & $\mathrm{X}$ & $\mathrm{X}$ & $x$ & & $\mathrm{X}$ & & \\
\hline Meristorygma & $\mathrm{X}$ & $\mathrm{X}$ & & $\mathrm{x}$ & & & & & & \\
\hline Kitakamithyris & $\mathrm{x}$ & t & & & & & & $x$ & & \\
\hline Phricodothyris & $\mathrm{X}$ & $\mathrm{X}$ & $\mathrm{X}$ & $\mathrm{X}$ & $\mathrm{X}$ & & $X$ & $\mathrm{X}$ & & $\mathrm{X}$ \\
\hline Crenispirifer & $\mathrm{x}$ & & & & & & & & & $\underline{x}$ \\
\hline Punctospirifer & $x$ & & & & $\mathrm{X}$ & & & $\mathrm{X}$ & $\mathrm{X}$ & \\
\hline Girtyella & $\mathrm{X}$ & & & & $\mathrm{X}$ & & & & & \\
\hline Gilleidae gen. nov. & $\mathrm{X}$ & & & & & & & & & \\
\hline Dielasmella & $\mathrm{x}$ & & & & & & & & & \\
\hline
\end{tabular}

upper Viséan of NW Europe. One of them, Retroplexus sp., is included in a genus known from the lastmentioned area and age; the other is new and the type species of a new genus (Ovetina truyolsi gen. et sp. nov.). The forth species is very interesting because it is the second richthofenioid known from the Cantabrian Mountains: Miroproductus posadai gen. et sp. nov. Miroproductus is, together with the North American Ardmosteges, one of the earliest representatives of this coral-like superfamily. The only other richthofenioid, Zalvera sp., was described from a Moscovian limestone in the eastern part of the Cantabrian Mountains by BRUNTON (1996).

The productides of the Suborder Productidina generally were adapted to a soft substrate, but some species from the Valdeteja Formation show also structures considered to be adaptations to reef-dwelling, such as an enlargement and modification of its trail leading to the development of a flange or gutter, as in Admoskovia cf. aljutovensis LAZAREV, 2000 (Fig. 3.3), a species from the lower Moscovian (Vereyan) of the Moscow region (the genus is also known from the Cuera Limestone). A gutter is also developed in Limbifera? sp. nov. (Fig. 3.4), a rare species better preserved in the Cuera Limestone (MARTíneZ Chacón \& BAHAMOnde 2008: fig. 2B-C). The trail could also extend anteriorly, forming a fold, as in Rugivestis? sp. (WINKLER Prins 2007, fig. 1A-B), probably a new species of a genus known from the Permian of North America and Russia, but also from the upper Bashkirian of Arctic Canada and Alaska (CARTer \& Poletaev 1998; Lazarev \& CARTer 2000). In Alitaria frechi (PAeckelmann, 1931), one of the most abundant species at Latores and Valdeteja, the trail is also extended (Fig. 3.5). The maximal development of the trail is observed in Productus concinnus (Sowerby, 1821) (Fig. 3.6-3.7). On the other hand, some productides, such as the small Incisiini gen. et sp. nov., have probably lived sheltered on the platform.

The orthotetides are another group of brachiopods which normally lived cemented to the substrate by the umbo of its pedicle valve. In the Valdeteja Formation, they are represented by four species (Table 2), e.g.,

Fig. 3. 1-2 - Plicatiferina sinecosta (MARTínez CHACón, 1979), two specimens, DPO 8850-8851, in ventral view, showing the clasping spines (arrows) attached to a crinoid stem, Latores; 3 - Admoskovia cf. aljutovensis LAZAREV, 2000, DPO 127807, in ventral view showing the gutter, Entrago; 4 - Limbifera? sp. nov., DPO 9445, ventral view of an incomplete specimen, Latores; 5 - Alitaria frechi (PAECKELMAN, 1931), DPO 9399, lateral view, Latores; 6-7 - Productus concinnus (SOWERBY, 1821) showing the great development of the trail, 6 - DPO 10078, ventral valve, 7 - DPO 10080, mould of dorsal disc, and ventral trail, Entrago; 8 - Meekella? ex gr. gigantea STUCKENBERG, 1905, DPO 127808, ventral view, Latores; 9 - Streptorhynchus? cf. subpelargonatus sensu DEMANET, 1934, DPO 127809, Latores; 10 - Parachoristites sp. DPO 127810, ventral valve, Latores; 11-12 - Alphachoristites (Prochoristites) sp., DPO 127811, ventral valve in ventral and posterior views, Latores. Scale bars $=2 \mathrm{~mm}$. 

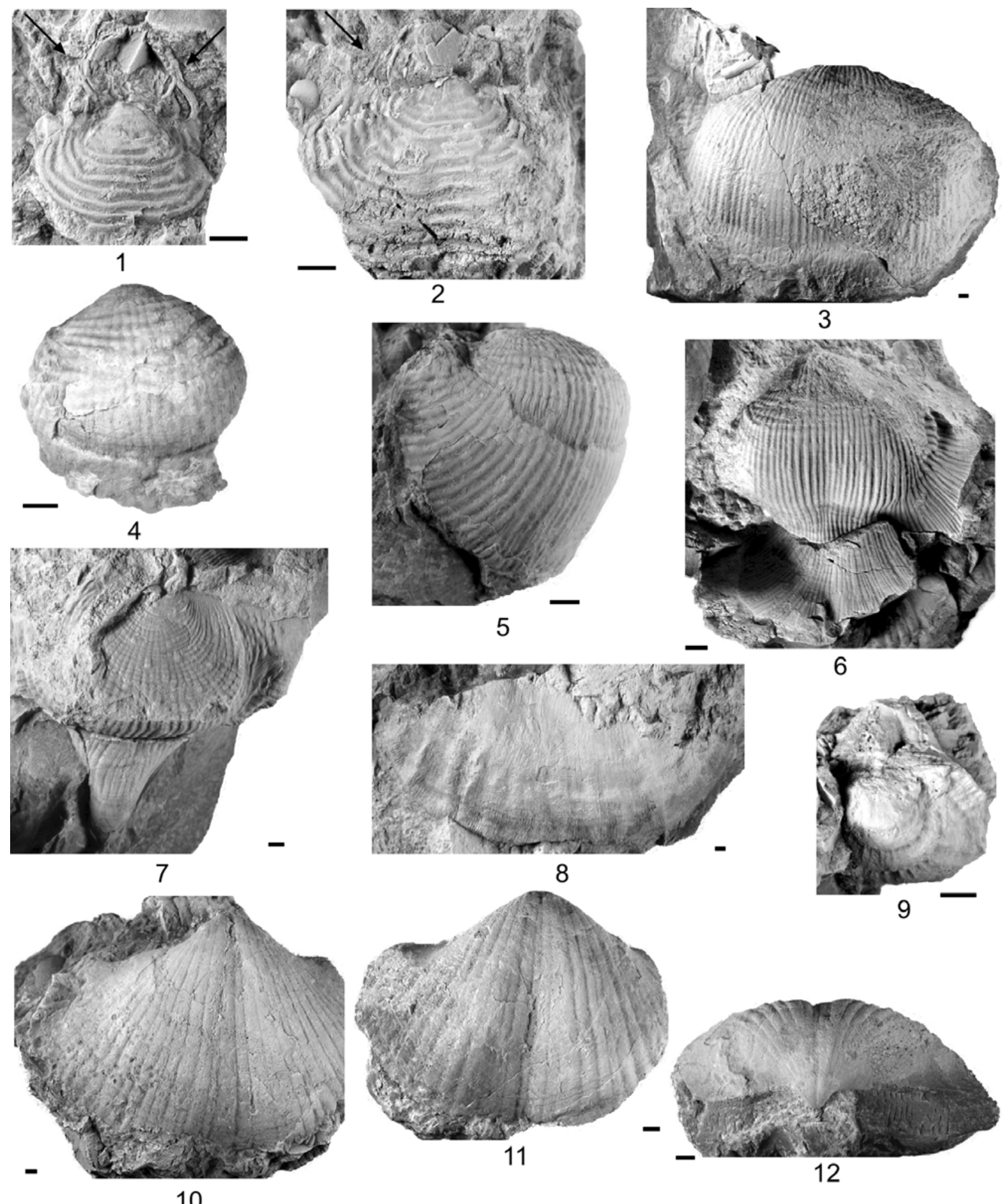

Fig. 3 (Legend see p. 98) 
a large species probably belonging to the genus Meekella (M.? ex gr. gigantea STUCKenBerG, 1905; Fig. 3.8), and Streptorhynchus? cf. subpelargonatus sensu DEMANET 1934, with a cicatrix and high ventral interarea (Fig. 3.9).

Many other brachiopod genera occurring in the Valdeteja Formation are common in a reef environment but occur also in other deposits, such as the orthids Rhipidomella and Orthotichia, the rhynchonellids Callaiapsida and Lambdarina, the latter being a small rhynchonellide, which lived sheltered in the reef (e.g., BRunton \& ChAMPION 1974; BASSETt \& BRYANT 1993: 518), possibly attached to algae or bryozoans. Rhynchopora also appears to be characteristic of a reef environment in Pennsylvanian and Permian times. This genus may have been derived from the Viséan genus Tretorhynchia. Several species of Athyrididina and the Retziidina Hustedia lived on the reefs, but not exclusively so since they were not particularly adapted to them. The same holds true for many representatives of the Spiriferida (Crurithyris, Tiramnia, Anthracospirifer, "Neospirifer", Gypospirifer, Phricodothyris) and Spiriferinida (Punctospirifer and Crenispirifer), but some forms were particularly well adapted to agitated water through their relatively large interareas (Cantabriella) and large size (Parachoristites [Fig. 3.10] and Alphachoristites (Prochoristites) [Fig. 3.11-3.12]). However, Cantabriella and Alphachoristites are also found in mudstone. The Terebratulida have no apparent adaptations to life on a reef, other than their pedicle attachment.

\section{Palaeobiogeographic connections (Table 3)}

The Viséan brachiopods from NW Europe (WolfENDEN 1958; BRUNTON 1966, 1968, 1984, 1987; Brunton \& Mundy 1988; Brunton \& TILsley 1991; BRUNTON et al. 1994; HARPER \& JEFFREY 1996) show close similarities at the generic level with the Valdeteja faunas, but for a large part these similarities could be due to the fact that specimens corresponding to new genera were provisionally attributed to Viséan genera, which show the same adaptations to life on a reef.

The relationship shown by the Pennsylvanian brachiopod faunas of the Cantabrian Mts with those from the Carnic Alps, Karavanke Mts (e.g., Ramovš 1971; Winkler Prins 1983; Martínez Chacón \& WinkLER PRINS 1993) and Bükk Mts (GulYÁs-KIS 2004) of Central Europe are less evident for the brachiopods from the Valdeteja Formation, due to their somewhat older age and different environment. The latter plays also a role when comparing the Valdeteja brachiopods with those from the Donnbass (Ukraine) and particularly the Moscow Platform (Russia). In the Urals, the carbonate platforms are poorly developed in the Bashkirian and the brachiopod faunas become richer towards the Permian, thus preventing a close comparison.

The close relationship with the brachiopods from the Hare Fiord Formation of Ellesmere Island (Canadian Arctic) - especially at the generic level, and much more so than with Spitsbergen and Greenland - is explained by the similar age and environment of that formation: upper Bashkirian or lower Moscovian bryozoan reef mounds (CARTER \& POLETAEV 1998: 106). Still, it seems very likely that the connection was through the Urals and the Arctic, although a direct connection through a branch of the Iberian-Midcontinent seaway cannot be excluded (see for example ERnst \& WinKLER PRINS 2008).

The connections with the Pennsylvanian faunas from the American Midcontinent were rather poor (see WINKLER PRINs 1983), but there are definite links with the Permian reef faunas from Texas (COOPER \& GRANT 1972-1977), which could have been through the Canadian Arctic. The presence of several taxa in Texas that may have been derived from NW Europe (cf. Mundy \& BRUnTON 1986) and which have no direct relatives known from the Canadian Arctic (and only partly from the Cantabrian Mts) is puzzling, but the excellent preservation of specimens from Great Britain and Texas with their spines attached make a direct comparison with the less well preserved Hare

Fig. 4. Ovetina truyolsi gen. et sp. nov. 1-2 - Holotype, DPO 38833, ventral and dorsal views; 3 - DPO 38834, decorticated dorsal interior with part of dorsal external mould, and gutter; 4 - DPO 38836, internal view of an incomplete ventral valve; 5 - DPO 38835, dorsal external mould and gutter; 6 - DPO 38837, dorsal view of a some decorticated and fragmentary specimen. 7-8 - DPO 39487, ventral view of a decorticated ventral valve with posterior part of ventral internal mould, showing median septum, muscle scars and large spines in left side; and internal view of the posterior part of valve. Scale bars $=2 \mathrm{~mm}$. 

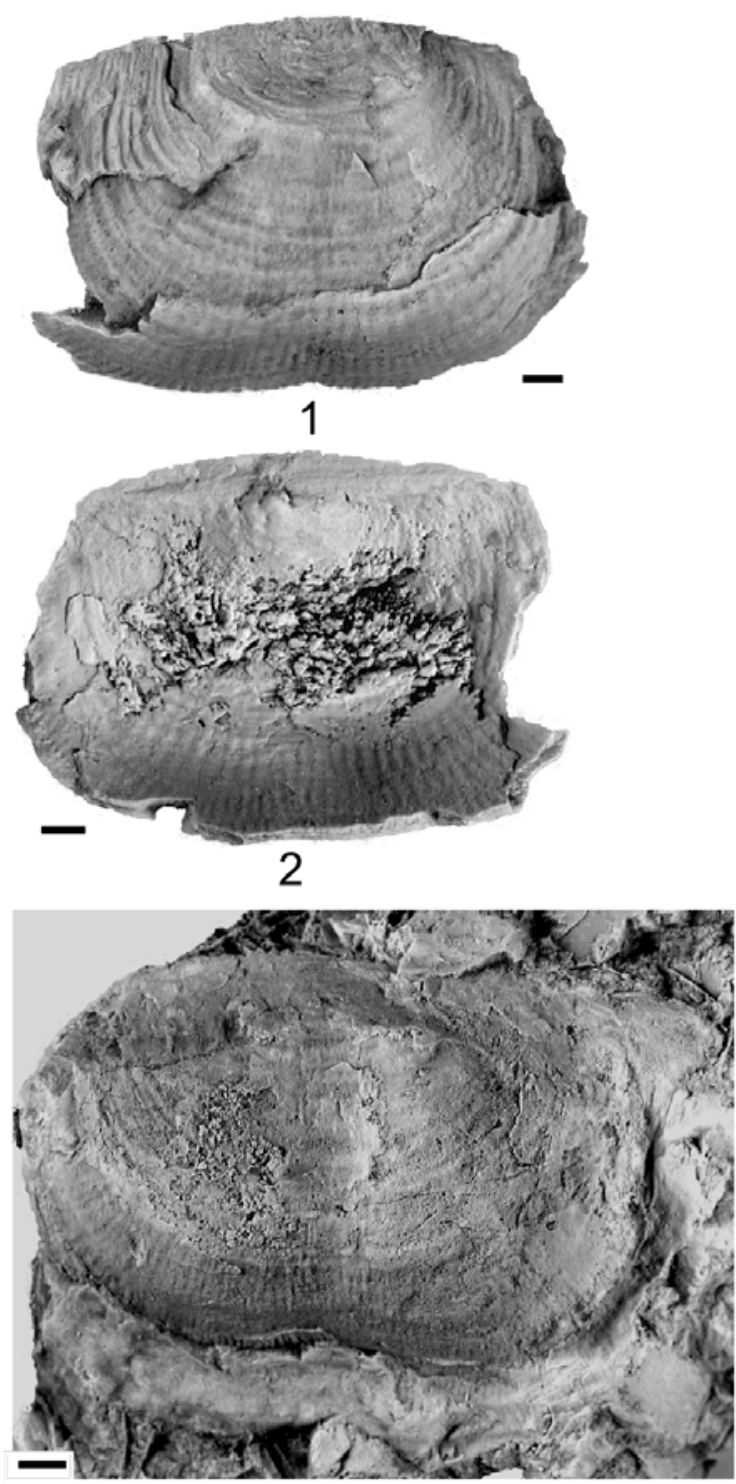

5

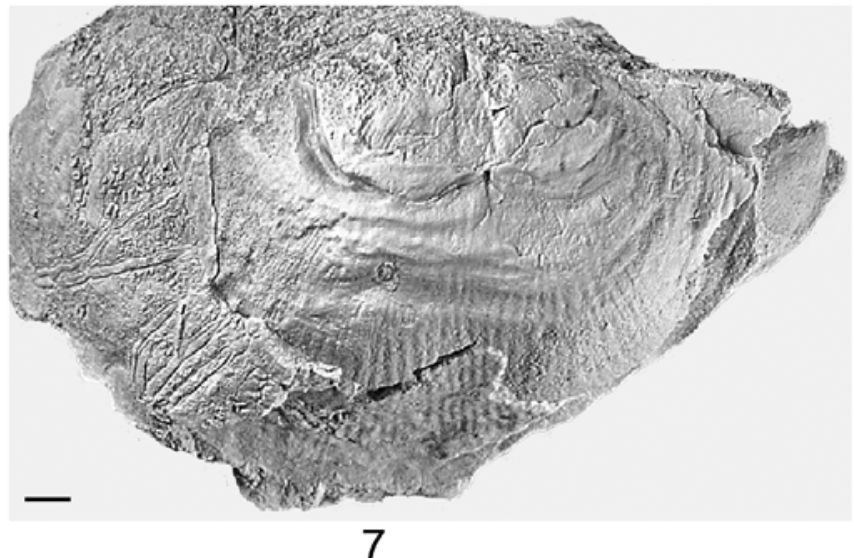

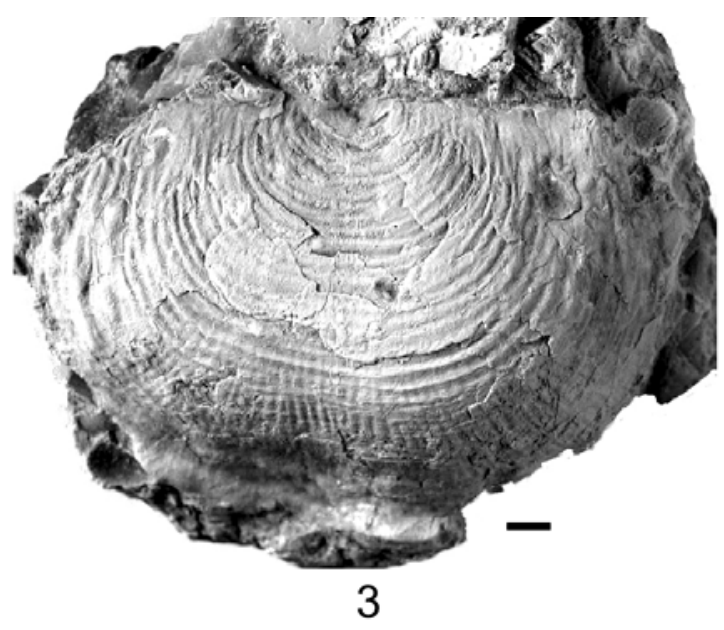

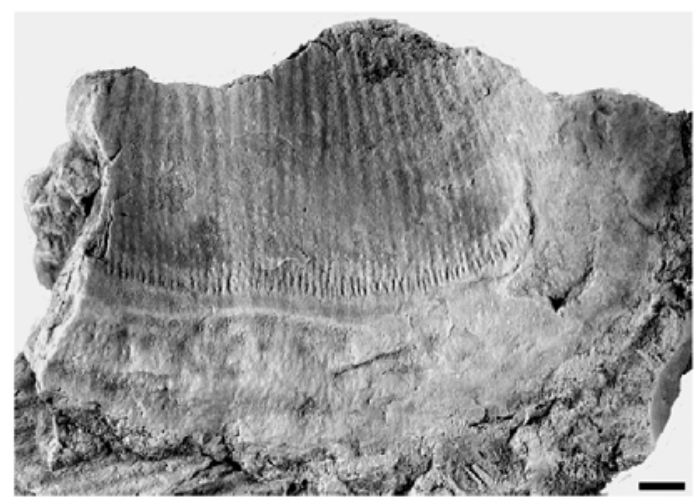

4

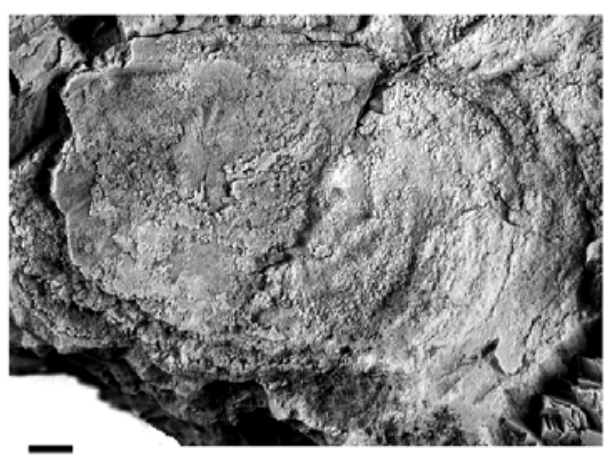

6

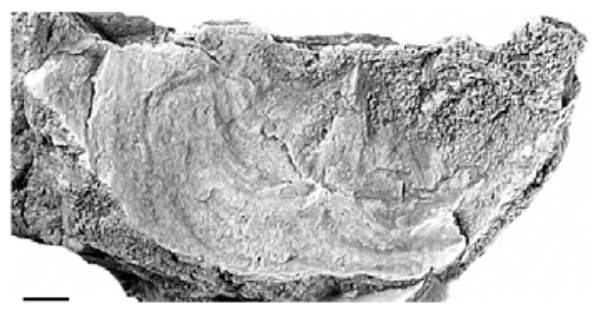

8

Fig. 4 (Legend see p. 100) 
Fiord and Spanish material difficult. Furthermore, these specialised forms are rather rare and could have been missed in the less extensively studied areas in Canada and Spain. These differences are in part due to the fact that brachiopods of British Isles and Texas are silicified and so much easier to extract from limestone.

\section{Conclusions}

The late Bashkirian-early Moscovian subsiding basin with carbonate platform deposits of the Valdeteja Formation in the Cantabrian Mountains was ideal for rich and varied benthonic faunas, especially brachiopods, and has apparently played an important role in providing a niche for the survival of reef-related brachiopod faunas during the Pennsylvanian, bridging the gap between the Mississippian brachiopods from reefoid deposits in northern Europe and the Permian faunas from reefs in the Urals and Texas. Surprisingly, they have their counterpart on Ellesmere Island in the Canadian Arctic, another refuge for these brachiopods during the Bashkirian-Moscovian, although the rare new forms specialised to a reef environment described below are missing there.

\section{Systematic palaeontology}

The specimens are deposited in the Geology Department of the University of Oviedo (numbers prefixed DPO) and the National Museum of Natural History of The Netherlands at Leiden (numbers prefixed RGM).

Order Productida Sarytcheva \& Sokolskaya, 1959 Suborder Strophalosiidina WATERHOUSE, 1978 Superfamily Aulostegoidea MUIR-WoOd \& COOPER, 1960

Family Aulostegidae Muir-Wood \& COOPER, 1960 Subfamily Institellinae MUIR-WoOd \& COOPER, 1960

\section{Genus Ovetina nov.}

Type species: Ovetina truyolsi gen. et sp. nov.

Etymology: The genus is named after the city of Oviedo (L: Ovetus) near which the type species was found.

Diagnosis: Institellinae with a semielliptic outline and weakly developed sulcus, ventral interarea with delthyrium filled by pseudodeltidium and lophidium, rather large cicatrix, ears small; rugose visceral ornamentation, becoming reticulate on the anterior part of corpus, trail costate, gutter well developed all around the margin; row of thin spines along hinge, row of large spines separating the ears and a few spines scattered on ventral visceral area. Dorsal valve concave with weakly developed fold, without interarea; ornamentation similar to that of the ventral valve but without spines; long median septum rising anteriorly from between the muscle scars, cardinal process externally bilobed.

Species included: Type species only.

Comparisons: The genus appears to have derived from Sinuatella MurR-Wood, 1928, from which it is distinguished by its weakly developed sulcus, large cicatrix, lack of costae on the posterior part, thin spines along the hinge and large spines separating the ears, which appear to be smaller than in Sinuatella (cf. BRUNTON \& MUNDY 1988: 66 f.).

\section{Ovetina truyolsi gen. et sp. nov.}

Fig. 4

2008 Institellinae gen. et sp. indet. - MARTínEZ CHACÓN \& WinkLer Prins, p. 195.

Etymology: The species is named after the highly esteemed professor emeritus Jaime TRUYOLS SANTONJA, father of the palaeontological school of Oviedo (see SÁnchez de PosAda \& García-Alcalde 1999).

Type locality and horizon: Latores, $6 \mathrm{~km} \mathrm{SW}$ of Oviedo (Asturias, N Spain) (Fig. 1); light gray limestone, upper part of the Valdeteja Formation, upper Bashkirian.

Material: Holotype, DPO 38833 (Fig. 4.1-4.2), and other 6 specimens, DPO 38834-38838, 39487, all from the type locality.

Fig. 5. Miroproductus posadai gen. et sp. nov. 1-3 - Holotype, DPO 9440, 1: lateral view (the specimen is partly decorticated) showing the wide flange with the mould of three protective endospines, the aulacoterma and the line of junction of the two stages of growth; 2: posterior view (the apical region is broken) showing the section of dorsal valve (arrowed) and the trail without endospines; 3 : fragment of ventral interior showing endospines and aulacoterma; 4-5 - DPO 9453, ventral and posterior views; 6-9-DPO 38839, 6-7: two specimens, $a$ on the left hand and $b$ on the right hand, in ventral and ventral anterior views showing the ring of spines around the venter; 8: view from the specimen $b$ showing the development of an irregular fold; 9: lateral view of specimen $a ; \mathbf{1 0 - 1 2}$ - DPO 38841, 10: lateral view showing the flange with protective spines (arrowed); 11: dorsal view of the flange (arrowed the same spines as in 10); 12: posterior view showing the irregular extensions of shell filling the region above the hinge line. All the specimens are from the type locality. Scale bars $=2 \mathrm{~mm}$. 

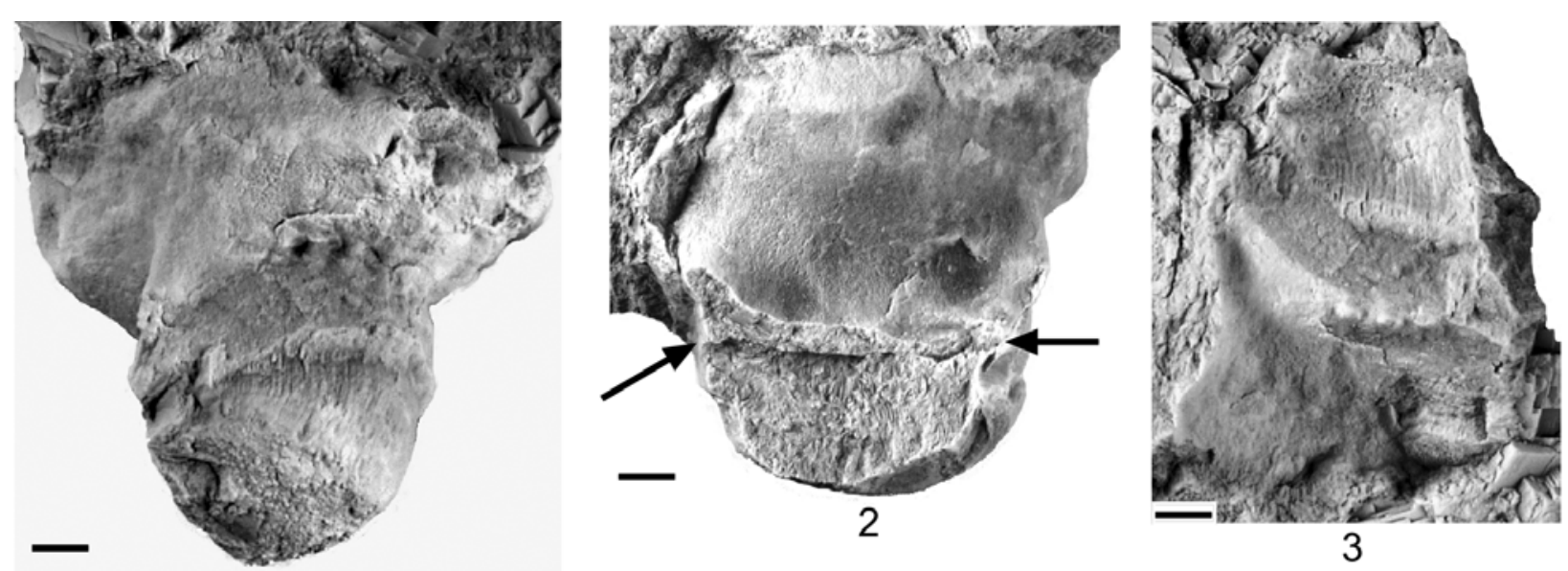
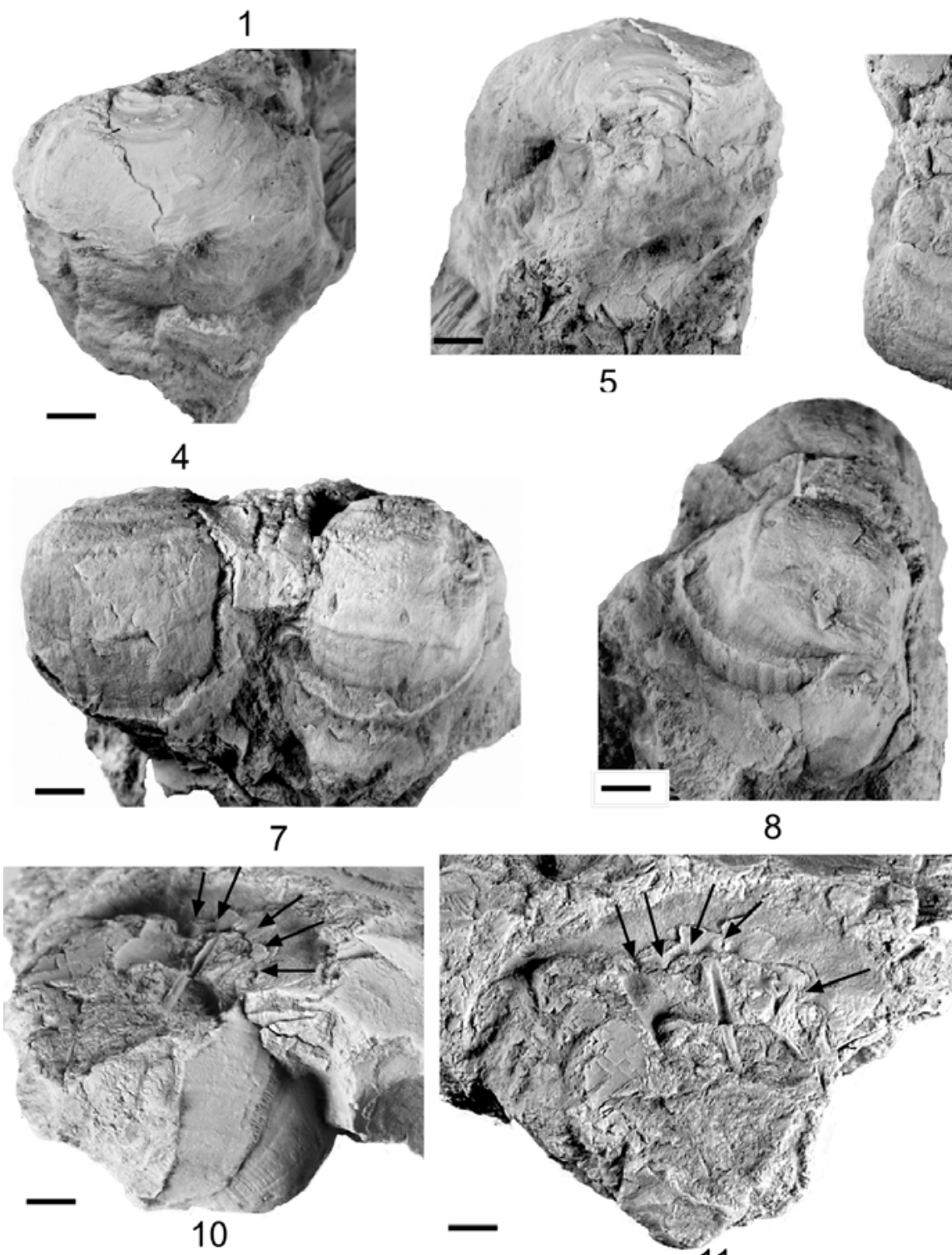

8

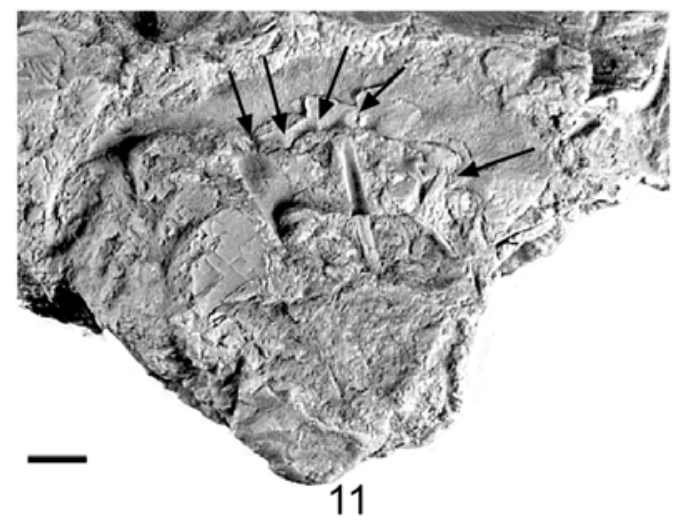

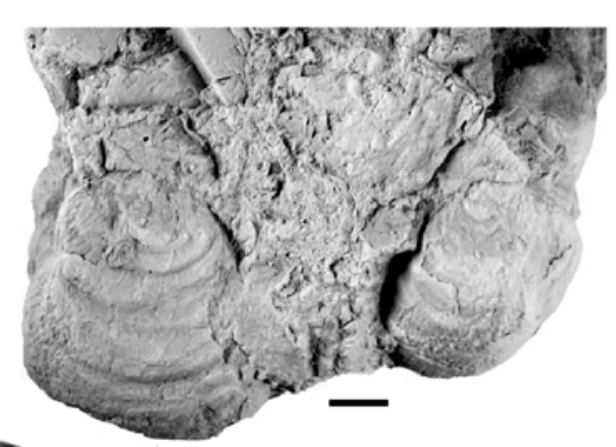

6
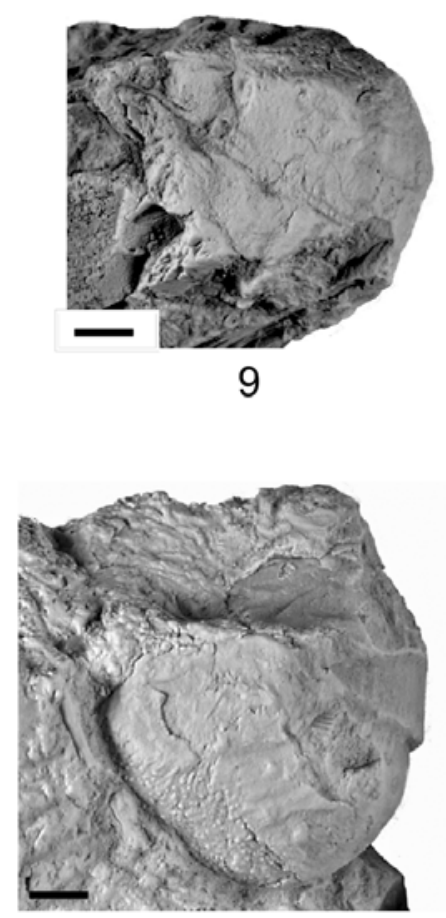

12

Fig. 5 (Legend see p. 102) 
Diagnosis: The genus is monospecific, so the generic diagnosis also applies to the species.

Description: Medium size: the holotype (an incomplete specimen lacking the bordering gutter) is $18.08 \mathrm{~mm}$ length and $25.25 \mathrm{~mm}$ width; the biggest specimen (DPO 38835 , Fig. 4.3) reaches $24.12 \mathrm{~mm}$ length and $\sim 36.50 \mathrm{~mm}$ width. Outline nearly semielliptic; maximum width at hinge line; strongly concavoconvex with shallow corpus cavity. Ornamentation of both discs by concentric regular rugae (about 5 per $5 \mathrm{~mm}$ in front of cicatrix); becoming reticulate on the anterior part of corpus and costate on trails (some 9-10 costae per $5 \mathrm{~mm}$ on trail); growth lines on trails may be lamellose. Gutter well developed all around the margin, reaching $6.40 \mathrm{~mm}$ in DPO 38836 (Fig. 4.4).

Ventral valve with weakly convex disc, abruptly bending to the trail. A weak median sulcus beginning at the anterior part of corpus and extends to the gutter. Interarea reaching almost $3 \mathrm{~mm}$ height; delthyrium filled by pseudodeltidium and lophidium; beak indistinct, not projecting posteriorly; large cicatrix of attachment reaching in the holotype $7 \mathrm{~mm}$ length and $10.8 \mathrm{~mm}$ width. Row of thin spines along hinge, row of thick rhizoid spines separating the ears and a few fine spines scattered on disc. Muscle scars well developed, separated by a median septum, with adductors and diductors well differentiate; interior surface pustulose, with pustulae forming ribs immediately before the interior of gutter; other internal details unknown.

Dorsal valve concave, with weakly developed fold, without spines. Internal characteristics difficult to observe: cardinal process externally bilobed, long median septum rising anteriorly from between the muscle scars, lateral ridges probably parallel to the hinge; other internal details not observed.

Discussion: For a comparison with Sinuatella sinuata (DE KONINCK, 1851) see the generic description. This species was listed by the authors as Institellinae gen. et sp. indet. (Martínez Chacón \& Winkler Prins 2008).

Superfamily Richthofenioidea WAAGEN, 1885 Family Cyclacanthariidae COOPER \& GRANT, 1975 Subfamily Teguliferinae MuIR-WoOd \& COOPER, 1960

\section{Genus Miroproductus nov.}

Type species: Miroproductus posadai gen. et sp. nov.
Etymology: The name refers to a "Productus" with peculiar (L: mirus) characteristics.

Diagnosis: Sphenoid (obliquely conical) ventral valve having an early aulostegid phase with large cicatrix and rhizoid spines, followed with an abrupt vertical bend by a richthofenioid stage with lateral margins of trails fused posteriorly and resting on the upper surface of the vestigial interarea; interior of valve shows a wide flange with protective spines emerging from its internal border at the anterior margin. Opercular dorsal valve apical throughout growth, leaving a vestibule above it.

Species included: Type species only.

Comparisons: Miroproductus resembles Ardmosteges (admirably described and depicted by SutHERLAND 1996) in its primitive richthofenioid character with an early aulostegoid stage of growth. However, the aulostegoid stage is better developed in our genus in detriment of the richthofenioid, which only reaches the last few millimetres of the shell. Moreover, both genera differ in that a wide internal flange bearing protective spines is developed in Miroproductus, which also has a larger cicatrix and a ventral cone shorter than that of Ardmosteges.

The early growth stages of Miroproductus resemble those of the genus Institina Muir-Wood \& COOPER, 1960, especially the illustration of I. marginalis (DE KONINCK, 1847) in the new Treatise (BRUNTON et al. 2000, fig. 428.1 e), which looks to have similar spines and flange, although in our material the growth continues after the development of the flange.

Discussion: Sutherland (1996) proposed that his genus Ardmosteges evolved from an aulostegoid ancestor, the upper Mississippian genus Sinuatella MUIR-Wood, 1928 being the most likely candidate. Miroproductus is also at the base of Richthofenioidea; its characteristics corroborate the aulostegoid origin for this superfamily as proposed by Sutherland. It is remarkable that both genera are of a similar (Bashkirian) age. However, the late Viséan genus Institina is more likely to be the ancestor of Miroproductus rather than Sinuatella (since they have the same initial general shape).

Miroproductus posadai gen. et sp. nov.

Figs. 5-6

1979 Alitaria frechi (Paeckelmann, 1931). - Martínez CHACón, p. 144 (pars).

Fig. 6. Miroproductus posadai gen. et sp. nov. 1-4 - DPO 38842, postero-ventral, lateral, posterior and lateral (the other side) views showing cicatrix, posterior spine bases, extensions of shell filling the region above the hinge (3), line of junction between aulostegid and richthofenioid stages, and one irregular lateral fold (1, 4), Latores; 5-7 - DPO 38851, La Manjoya, 5-6: lateral and posterior views; 7: fragmentary ventral interior; 8-10 - DPO 38854, dorsal, dorsal tilted and lateral views of an incomplete juvenile specimen showing the concentric ornamentation, Entrago; 11-13 - DPO 38853, Entrago, 11-12: ventral and dorsal views of a juvenile specimen showing the interarea; 13: dorsal external mould; 14 - RGM 288957, ventral view, Latores. Scale bars $=2 \mathrm{~mm}$. 

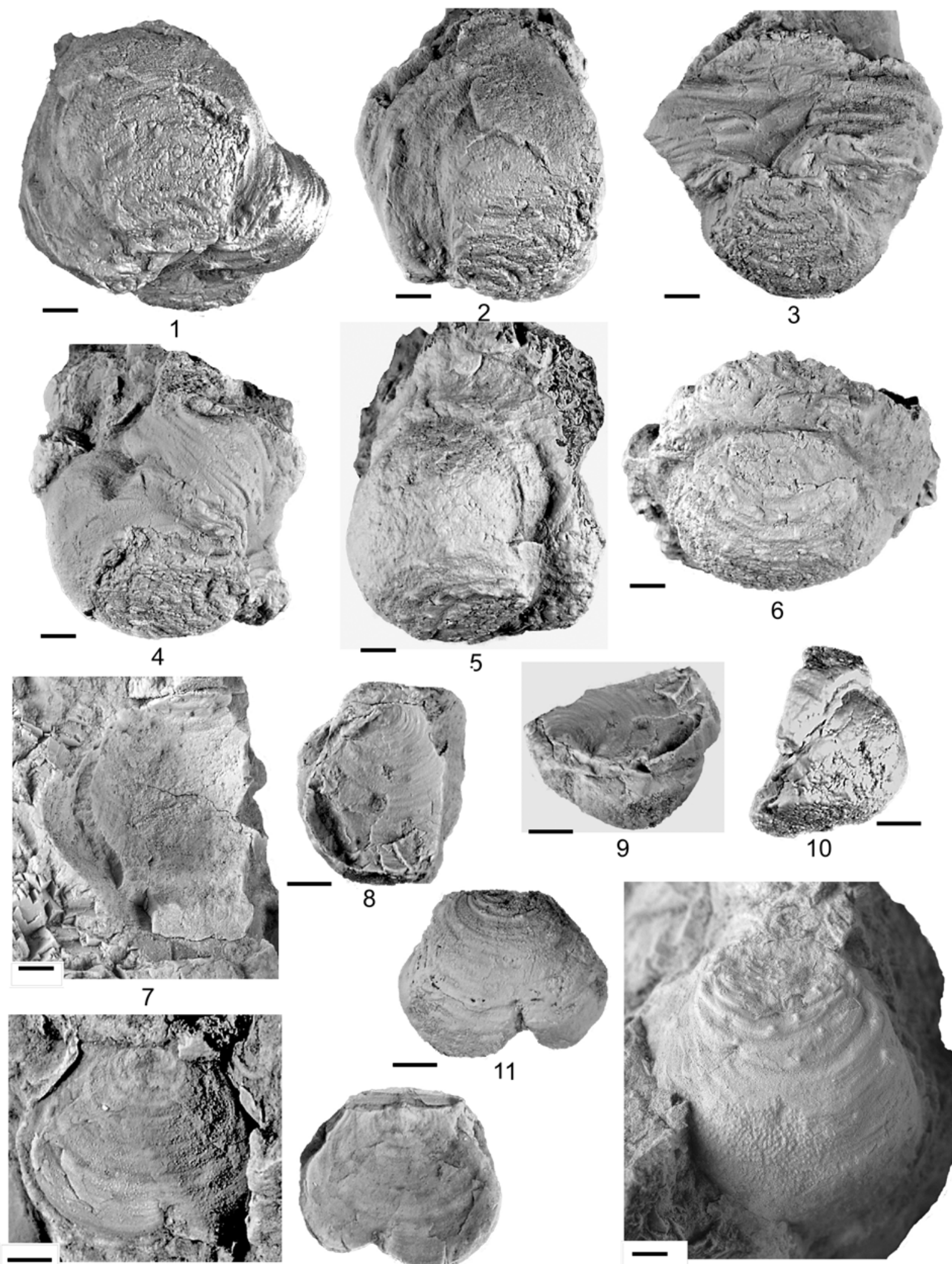

13
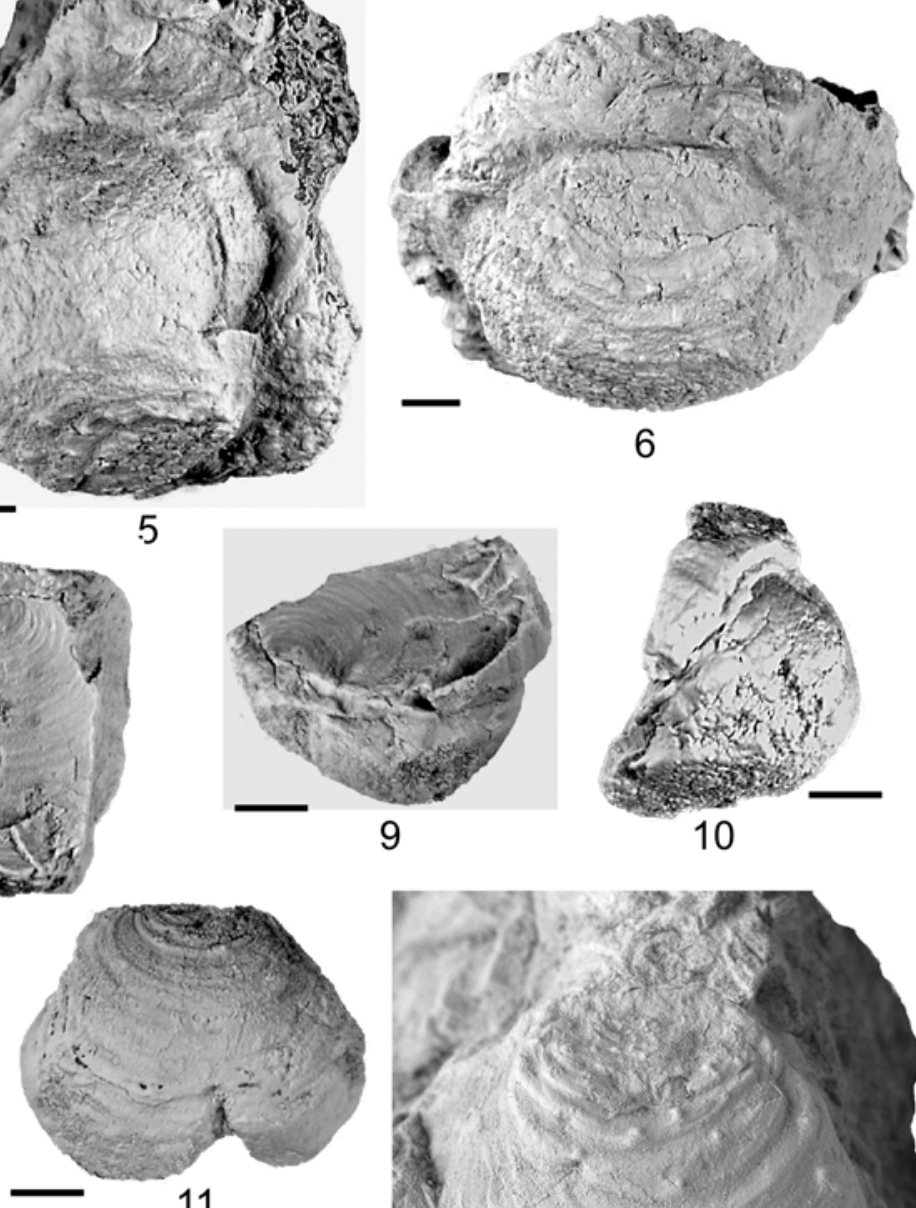

9

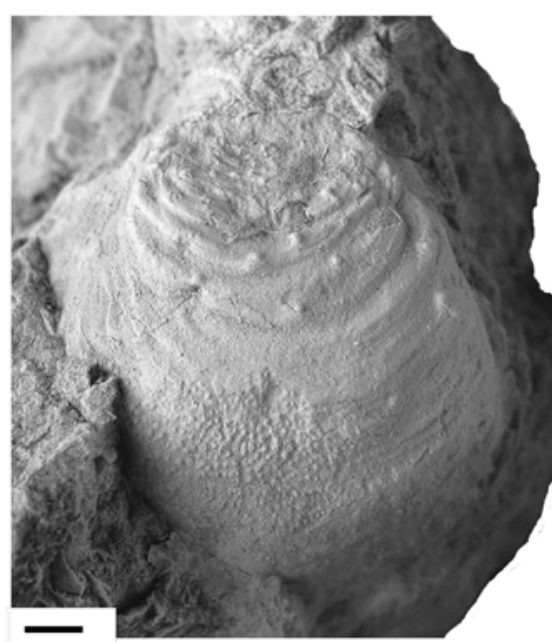

14

Fig. 6 (Legend see p. 104) 
Table 4. Measurements (in mm) of Miroproductus posadai gen. et sp. nov.

\begin{tabular}{|c|c|c|c|c|c|}
\hline Number & Length & Width & Hinge width & Heigth & Surface length \\
\hline DPO 38853 & 6.95 & 8.77 & 5.72 & & 15.67 \\
\hline DPO 38854 & 8.89 & & & & 17.67 \\
\hline Holotype & 19.2 & 20.63 & & 18.16 & \\
\hline DPO 9453 & 13.96 & $>14.05$ & & 13.38 & $>24.22$ \\
\hline DPO38839b & 12.53 & 14.41 & 3.98 & 12.57 & 19.13 \\
\hline DPO $38839 a$ & 12.52 & 11.63 & 3.32 & 10.61 & 18.4 \\
\hline DPO 38840 & 12.28 & $>13.97$ & 5 & 12.24 & $\sim 20.21$ \\
\hline DPO 38841 & 16.51 & $\sim 18.93$ & 6.06 & 11.53 & $\sim 27.12$ \\
\hline DPO 38851 & 17.88 & 18.94 & 6.33 & 15.71 & 28.62 \\
\hline DPO 38852 & 13.83 & 14.82 & 5.1 & & \\
\hline DPO 38842 & 17.65 & 17.29 & 5.08 & 16.04 & 24.92 \\
\hline DPO 38843 & $>12.33$ & $>15.41$ & 5.7 & $>11.51$ & $>22.08$ \\
\hline RGM 290597 & 13.0 & 13.0 & 10.4 & & \\
\hline RGM 288961 & 8.0 & 14.6 & 14.6 & $>5$ & \\
\hline RGM 288958 & 9.0 & 10.6 & 9.7 & $>4$ & \\
\hline
\end{tabular}

2007 Institina? sp. - WINKLER PrINS, pl. 1, fig. 4 (pars, non fig. 5).

2008 Institina? sp. - MARTínez CHACón \& WinkleR PRINS, p. 195.

Etymology: The species is named after Professor LuIS C. SÁnchez de Posada (Department of Geology, Oviedo University), husband of M. L. MARTínez CHACón, who helped a lot collecting the material in the field.

Type locality and horizon: Latores, $6 \mathrm{~km} \mathrm{SW}$ of Oviedo (Asturias, N Spain) (Fig. 1); light gray limestone, upper part of the Valdeteja Formation, upper Bashkirian.

Material: Holotype, DPO 9440 (Fig. 5.1-5.3), and 23 other specimens, DPO 9434-9435, 9453, 9180B, 38839-38850, and RGM 288957, 288961, 290597 from the type locality; two specimens, DPO 38851-38852, from La Manjoya, a locality close to the type one; and two specimens, DPO 38853-38854 from Entrago (Teverga, Asturias, Fig. 1; this is loc. B129 of MARTínez CHACón 1979). All from the upper part of the Valdeteja Formation, upper Bashkirian.

Diagnosis: The genus is monospecific, so the generic diagnosis also applies to the species.

Description: Ventral valve with interarea well visible in early growth stages; delthyrium closed (it is impossible to discriminate the kind of plate); beak indistinct, not projecting posteriorly. Hinge line relatively narrow; posterolateral extremities of dorsal valve project laterally and fit in articulation grooves located just anteriorly to the extremities of the ventral interarea (Fig. 6.12). Large, flat cicatrix of attachment reaching some $6 \mathrm{~mm}$ in length. A few millimetres in front of this cicatrix, the valve becomes dorsally geniculated; at the same time, the shell began to fill gradually the posterior region above the hinge line by adding shell material posteriorly to the lateral slopes, as far as they became fused on the upper surface of the interarea, at a short distance from the apex, leaving clear vestiges of this structure. This process continues until the posterior margin equalled the anterior trail; then, growth bands became continuous around the valve for a few millimetres (up to $5.5 \mathrm{~mm}$ in DPO 38842, Fig. 6.3). A clear line marks the junction of the two kinds of growth (Figs. 5.1-5.2, 6.1, $6.3)$. Externally, the growth lines or bands, which are irregular in the posterior region, sometimes give rise to rugae. Patches of rhizoid spines are situated on the posterior part, at both sides of venter; moreover, circular spine bases are situated close to each other forming a ring around the venter, just before the geniculation; on the rest of the cone, scattered spine bases are seen; the posterior part of the venter has thinner spine bases. The ventral valve shows a thickening around its interior (the aulacoterma) on which the dorsal valve rests when the shell is closed (Fig. 5.1, $5.7-5.8,5.10)$, so leaving a vestibule above it. At some distance in front of the aulacoterma, a wide flange is developed, all around the valve; the internal border of the flange bears protective spines except, apparently, in the region above the interarea (see the holotype, Fig. 5.2).

Dorsal valve opercular, remaining in its original position throughout growth; exterior only known in juvenile specimens, with even growth lines and no spines; cardinal process extending posteriorly above hinge; other internal details not observed.

Owing to the attachment, the general aspect of the shell is irregular. The ventral cones are oblique in many specimens but they become vertical with growth. Two specimens develop irregular, more or less vertical folds (Figs. $5.8,6.1,6.4)$. In some cases, the upper part of the cone is undulate.

Measurements of some specimens are given in Table 4. They were taken in the same way as SutherLAND did (1996, fig. 9).

Discussion: The earliest formed part of the shell, with geniculated dorsal valve, the internal thickening of the aulacoterma and the ring of big spine bases resemble a marginiferid in the sense of the old Treatise (MUIR-WOOD 1965). For this reason, the holotype (which was partially 
included in the matrix) and other four specimens were previously put in the species Alitaria frechi, which is very abundant in the locality of Latores (MARTínez CHACÓN 1979; Martínez Chacón \& Winkler Prins 2007). As stated before, Miroproductus also resembles Institina; and this species was listed by us as Institina? sp. (MARTíneZ Chacón \& Winkler Prins 2008; Winkler Prins 2007).

The differences between the new species and Ardmosteges orchamus SUTHERLAND, 1996, type species of the monospecific genus, are the same as those between Ardmosteges and Miroproductus.

\section{Acknowledgements}

Professor Luis C. SÁNCHEz DE Posada (University of Oviedo) is thanked for his assistance in the field. Thanks are also due to JOAQUín VÁZQUEZ VARELA (University of Oviedo) for taking the photographs and to BAS BLANKEVOORT (National Museum of Natural History, Leiden) for drawing Figure 2. We are also grateful to the referees Professor GuANG SHI (Deaking University, Melbourne) and Dr Susan ButTs (Peabody Museum of Natural History, Yale University) for their constructive comments which helped us to improve the manuscript. The second author (C.F.W.P.) wishes to thank the A. Buitendijk Foundation for contributing to the travelling costs enabling him to visit the first author (M.L.M.Ch.) in Oviedo to discuss the material from Latores. The paper is a contribution to the project CGL 2006-04554 of the Spanish Department of Science and Technology.

\section{References}

Amler, M. R. W. \& Winkler Prins, C. F. (1999): Lower Carboniferous bivalves from the Cantabrian Mts (Spain). - Scripta Geologica, 120: 1-45.

Babin, C., García-Alcalde, J., Gutiérrez-Marco, J. C. \& Martínez-Chacón, M. L. (1999): Conocardiacea (Mollusca, Rostroconchia) du Dévonien et du Carbonifère d'Espagne. - Revue de Paléobiologie, 18: 173186.

BARRoIs, C. (1882): Recherches sur les terrains anciens des Asturies et de la Galice. - Mémoire de la Société géologique du Nord, 2 (1): 1-630.

Bassett, M. G. \& Bryant, C. (1993): The micromorphic rhynchonelloidean brachiopod Lambdarina from the type Dinantian. - Journal of Paleontology, 67: 518-527.

Becker, G. (1982): Fazies-anzeigende Ostracoden-Vergesellschaftungen aus dem frühen Oberkarbon des Kantabrischen Gebirges (N-Spanien). - Neues Jahrbuch für Geologie und Paläontologie, Abhandlungen, 164: 307338.

Bless, M. J. M. \& Sánchez de Posada, L. C. (1973): Sobre la aparición de Ostrácodos nectónicos en la Cordillera Cantábrica. - Breviora Geológica Astúrica, 17: 25-30.

Boll, F. C. (1985): Rugose Korallen der FlachwasserFazies im Oberkarbon des Kantabrischen Gebirges (Nordspanien). - Palaeontographica, (A), 190: 1-81.
Boogatrd, M. van den \& Bless, M. J. M. (1985): Some conodont faunas from the Aegiranum Marine Band. Proceedings of the Koninklijke Nederlandse Akademie van Wetenschappen, serie B, 88: 133-154.

Bowman, M. B. J. (1982): The stratigraphy of the San Emiliano Formation and its relationship to other Namurian/Westphalian A sequences in the Cantabrian Mts., NW Spain. - Trabajos de Geología, 12 [Volumen homenaje a Charles Barrois (1851-1939) en el centenario de la publicación de las "Recherches sur les terrains anciens des Asturies et de la Galice" (1882)]: 23-35.

- (1985): The sedimentology and palaeogeographic setting of late Namurian-Westphalian A basin-fill successions in the San Emiliano and Cármenes areas of NW León, Cantabrian Mts, NW Spain. - In: Lemos DE Sousa, M. J. \& Wagner, R. H. (Eds.): Papers on the Carboniferous of the Iberian Peninsula (sedimentology, stratigraphy, palaeontology, tectonics and geochronology). - Anais da Faculdade de Ciências, Universidade do Porto, Supplement to volume 64 (1983: Special volume in honour of WENCESLAU DE LIMA, palaeobotanist and statesman [1858-1919]): 117-169.

Brouwer, A. \& van Ginkel, A. C. (1964): La succession carbonifère dans la partie méridionale des Montagnes Cantabriques (Espagne du Nord-Ouest). - Compte Rendu du V Congrès International de Stratigrafie et de Géologie du Carbonifère, Paris, 1963, 1: 307-319.

Brunton, C. H. C. (1966): Silicified brachiopods from the Viséan of County Fermanagh. - Bulletin of the British Museum (Natural History), Geology Series, 12: 175243.

- (1968): Silicified brachiopods from the Viséan of County Fermanagh, II. - Bulletin of the British Museum (Natural History), Geology Series, 16: 1-70.

- (1984): Silicified brachiopods from the Viséan of County Fermanagh, Ireland (III). Rhynchonellids, Spiriferids and Terebratulids. - Bulletin of the British Museum (Natural History), Geology Series, 38: 27-130.

- (1987): The palaeoecology of brachiopods, and other faunas, of Lower Carboniferous (Asbian) limestones in West Fermanagh. - Irish Journal of Earth Sciences, 8: 97-112.

- (1996): A new protorichthofenoid brachiopod (Productida) from the Upper Carboniferous of the Urals, Russia. - Bulletin of the Natural History Museum London (Geology), 51: 51-59.

Brunton, C. H. C. \& Champion, C. (1974): A Lower Carboniferous brachiopod fauna from the Manifold Valley, Staffordshire. - Palaeontology, 17: 811-840.

Brunton, C. H. C., Lazarev, S. S., Grant, R. E. \& Jin Yu-Gan (2000): Productidina. - In: Williams, A. et al.: Treatise on Invertebrate Paleontology. Part H. Brachiopoda Revised. Vol. 3: Linguliformea, Craniiformea, and Rhynchonelliformea (part), 424-609; Boulder \& Lawrence (Geological Society of America \& University of Kansas).

Brunton, C. H. C. \& Mundy, D. J. C. (1986): Some Dinantian chonopectinid productaceans (Brachiopoda) from the British Isles. - Proceedings of the Yorkshire Geological Society, 46: 1-10. 
Brunton, C. H. C. \& Mundy, D. J. C. (1988): Strophalosiacean and aulostegacean productoids (Brachiopoda) from the Craven Reef Belt (late Viséan) of North Yorkshire. - Proceedings of the Yorkshire Geological Society, 47: 55-88.

Brunton, C. H. C., Mundy, D. J. C. \& Lazarev, S. S. (1994): Productellid and Plicatiferid (Productoid) Brachiopods from the Lower Carboniferous of the Craven Reef Belt, North Yorkshire. - Bulletin of the British Museum of Natural History (Geology), 49: 99-119.

Brunton, C. H. C. \& Tilsley, J. W. (1991): A check list of brachiopods from Treak Cliff, Derbyshire, with reference to other Dinantian (Lower Carboniferous) localities. - Proceedings of the Yorkshire Geological Society, 48: 287-295.

Carballeira, J., Corrales, I., Valladares, I., Naval, A., Ruiz, F., Lorenzo, S., Martínez Chacón, M. L., Méndez, C., SÁnchez de Posada, L. C. \& Truyols, J. (1985): Aportaciones al conocimiento de la estratigrafía de la Formación San Emiliano (Carbonífero, Cordillera Cantábrica) en su área-tipo. - Compte Rendu Dixième Congrès International de Stratigraphie et de Géologie du Carbonifère, Madrid, 1983, 1: 345-362.

Carter, J. L. \& Poletaev, V. I. (1998): Atokan (Late Bashkirian or Early Moscovian) brachiopods from the Hare Fiord Formation of Ellesmere Island, Canadian Arctic Archipelago. - Annals of the Carnegie Museum, 67: 105-180.

Chao, Y. T. (1929): Carboniferous and Permian Spiriferids of China. - Palaeontologia Sinica, (B), 11 (1): 134 pp.

Cooper, G. A. \& Grant, R. E. (1972-1977): Permian Brachiopods of West Texas, I-VI. - Smithsonian Contributions to Paleobiology, 1972, 14: 1-231, pls. 1-23; 1974, 15: 233-793, pls. 24-191; 1975, 19 (1): 795-1921; (2): pls. 192-502; 1976, 21 (1): 1923-2607; (2); pls. 503-662; 1976, 24: 2609-3159, pls. 663-780; 1977, 32: 3161-3370.

Defrance, M. J. L. (1826): Article Productus. - In: Dictionnaire des Sciences Naturelles, 43: 349-355; Paris.

DeléPINE, G. (1943): Les faunes marines du Carbonifère des Asturies (Espagne). - Mémoires de l'Académie des Sciences de l'Institut de France, 66 (3): 114 pp.

Delépine, G. \& Llopis Lladó, N. (1956): Nouvelle faune Carbonifère à Latores (Asturies, Espagne). - Comptes Rendus sommaires des Séances de la Société Géologique de France, 1956: 106-108.

Demanet, F. (1934): Les brachiopodes du Dinantien de la Belgique. 1er vol.; Atremata, Neotremata, Protremata (pars). - Mémoires du Musée Royal d'Histoire Naturelle de Belgique, 61: $107 \mathrm{pp}$.

Dunbar, C. O. \& Condra, G. E. (1932): Brachiopoda of the Pennsylvanian System in Nebraska. - Nebraska Geological Survey Bulletin, 2 ser., 5: 377 pp.

EICHMÜlleR, K. (1985): Die Valdeteja Formation: Aufbau und Geschichte einer oberkarbonischen Karbonatplattform (Kantabrisches Gebirge, Nordspanien). - Facies, 13: $45-154$.
Ernst, A. \& Winkler Prins, C. F. (2006): Oberkarbonische Bryozoen aus dem Kantabrischen Gebirge, Nordspanien. - 76. Tagung der Paläontologischen Gesellschaft, Kiel, 2006: "Paläontologie zwischen Land und Meer". Abstract/Poster.

- (2008): Pennsylvanian bryozoans from the Cantabrian Mountains (N Spain). - Scripta Geologica, 137: 1-123.

EZQUERRA DEL BAYO, J. (1844): Descripción geognóstica y minera de la provincia de Palencia. - Boletín Oficial de Minería, 14: 160-163.

FERnÁNDEZ, L. P. (1993): La Formación San Emiliano (Carbonífero de la Zona Cantábrica, NO de España): estratigrafía y extensión lateral. Algunas implicaciones paleogeográficas. - Trabajos de Geología, 19: 97-122.

Fleming, J. (1828): A History of British Animals, exhibiting the Descriptive Characters and Systematic Arrangement of the Genera and Species of Quadrupeds, Birds, Reptiles, Fishes, Mollusca and Radiata of the United Kingdom. - 565 pp.; Edinburgh (Bell \& Bradfute).

FlÜGel, E. \& Kiessling, W. (2002): A new look at ancient reefs. - In: Kiessling, W., Flügel, E. \& GolonKA, J. (Eds.): Phanerozoic reef patterns. - SEPM Special Publication, 72: 3-10.

GandL, J. (1987): Trilobiten aus dem höheren Namur und tieferen Westfal. - Abhandlungen der Senckenbergischen Naturforschenden Gesellschaft, 543: 1-79.

García-Bellido Capdevila, D. (2002): Demosponjas y Hexactinélidas fósiles de la Península Ibérica. - Coloquios de Paleontología, 53: 109-136.

Ginkel, A. C. van \& Villa, E. (1996): Palaeontological data of the San Emiliano Formation (Cantabrian Mountains, Spain) and their significance in the Carboniferous chronostratigraphy. - Géobios, 29: 149-170.

Grant, R. E. (1971): Brachiopods in the Permian reef environment of West Texas. - Proceedings of the North American Paleontological Convention, Chicago, 1969, 2: 1444-1481.

GulYÁs-Kis, C. (2004): Palaeobiogeographic analysis of Moscovian (Pennsylvanian) brachiopods Productida, Orthotetida, Orthida, Rhynchonellida from Bükk Mts, Hungary. - In: KÁzmér, M. (Ed.): Shallow Tethys 6 Symposium proceedings, Budapest, 2003. - Hantkeniana, 4: 17-35.

Harper, D. A. T. \& JefFrey, A. L. (1996): Mid-Dinantian brachiopod biofacies from western Ireland. - In: Strogen, P., Somerville, I. D. \& Jones, G. L. (Eds.): Recent Advances in Lower Carboniferous Geology. Geological Society, Special Publication, 107: 427-436.

KInG, R. H. (1933): Neospirifer dunbari RHalph H. KING, nom. nov. - Journal of Paleontology, 7: 441.

KonINCK, L. G. DE (1841-1844): Description des animaux fossiles qui se trouvent dans le terrain Carbonifère de Belgique. - 650 pp.; Liège (Dessain).

- (1847): Recherches sur les animaux fossiles, Part I. Monographie des genres Productus et Chonetes. - 246 pp.; Liège (Dessain).

- (1851): Description des animaux fossiles qui se trouvent dans le terrain Carbonifère de Belgique. Supplément. 651-716; Liège (Dessain). 
LAPINA, N. N. (1957): Brakhiopody kamennougol'nykh otlozhenij Permskogo priural'ya [Carboniferous brachiopods from the Permian Preurals]. - Trudy VNIGRI, 108: 132 pp. [In Russian].

LAZAreV, S. S. (2000): Brachiopods of the Tribe Reticulatiini from the Carboniferous of the Moscow Region: Part 2. On the systematic position of Reticulatiini, with proposed sister-tribes and the description of a new genus, Admoscovia. - Paleontological Journal, 34 (5): 495-503. [Translation of Paleontologicheskii Zhurnal, 2000 (5): 25-33].

LAZARev, S. S. \& CARTER, J. L. (2000): New Atokan brachiopods from the Upper Carboniferous Ladrones Limestone of southeastern Alaska, with a preliminary note on the phylogeny and classification of the Tribe Retariini. Annals of Carnegie Museum, 69 (1): 11-21.

LÉveILlé, C. (1835): Aperçu géologique de quelques localités très riches en coquilles sur les frontières de France et de Belgique. - Mémoire de la Société géologique de France, 2: 29-40.

M'Coy, F. (1844): A synopsis of the characters of the Carboniferous Limestone fossils of Ireland. - 207 pp.; Dublin (University Press).

Martínez Chacón, M. L. (1977a): New Carboniferous stenoscismatacean brachiopods from Oviedo and León, Spain. - Palaeontology, 20: 209-223.

- (1977b): Contenido en braquiópodos (Orthida, Strophomenida y Rhynchonellida) de algunas formaciones del Carbonífero cantábrico. - Breviora Geológica Astúrica, 21: 41-48.

- (1979): Braquiópodos Carboníferos de la Cordillera Cantábrica (Orthida, Strophomenida y Rhynchonellida). - Memoria del Instituto Geológico y Minero de España, 96: $291 \mathrm{pp}$.

Martínez Chacón, M. L. \& Bahamonde, J. R. (2008): Brachiopods from a steep-slope facies of a Pennsylvanian carbonate platform (Sierra del Cuera, Asturias, N Spain). - In: Harper, D. A. T., Long, S. L. \& Nielsen, C. (Eds.): Brachiopoda: Fossil and Recent. Fossils and Strata, 54: 133-143.

Martínez Chacón, M. L., Menéndez Állvarez, J. R., SÁnchez de Posada, L. C. \& Truyols, J. (1985): Aportaciones al conocimiento de la Formación Ricacabiello (Carbonífero de la Zona Cantábrica, N de España) y su contenido paleontológico. - Trabajos de Geología, 15: 53-65.

Martínez Chacón, M. L. \& Winkler Prins, C. F. (1993): Carboniferous brachiopods and the palaeogeographic position of the Iberian Peninsula. - Compte Rendu XII Congrès International de Stratigraphie et de Géologie du Carbonifère et Permien, Buenos Aires, 1991, 1: 573-580.

- (2006) Braquiópodos de la Formación Valdeteja (Pensilvánico, Cordillera Cantábrica, $\mathrm{N}$ de España). - In: Fernández Martínez, E. (Ed.): XXII Jornadas de la Sociedad Española de Paleontología. Libro de Resúmenes, 145-147; Universidad de León.

- (2007): Medio siglo de estudio de los Braquiópodos del yacimiento de Latores. - I Congreso de Estudios Asturianos, Oviedo, 2006, 6: 309-329.
Martínez Chacón, M. L. \& Winkler Prins, C. F. (2008): Some new Bashkirian (Carboniferous) brachiopods from Latores (Asturias, N Spain). - Proceedings of the Royal Society of Victoria, 120: 194-205.

Méndez, C. A. \& Menéndez Álvarez, J. R. (1985): Conodontos carboníferos de las regiones del Manto del Ponga y Picos de Europa (Oriente de Asturias, $\mathrm{N}$ de España). Compte Rendu Dixième Congrès International de Stratigraphie et de Géologie du Carbonifère, Madrid, 1983, 1: 71-82.

Moore, L. R., Neves, R., Wagner, R. H. \& WagnerGENTIS, C. H. T. (1971): The stratigraphy of Namurian and Westphalian rocks in the Villamanín area of northern León, N.W. Spain. - In: WAGner, R. H. (Ed.): The Carboniferous of Northwest Spain, 1. - Trabajos de Geología, 3: 307-363.

Muir-Wood, H. M. (1928): The British Carboniferous Producti. II. Productus (sensu stricto) semireticulatus and longispinus groups. - Memoirs of the Geological Survey of Great Britain, Palaeontology, 3 (1): 217 pp.

Muir-Wood, H. M. (1965): Productidina. - In: Moore, R.C. (Ed.): Treatise on Invertebrate Paleontology, Part H, Brachiopoda, vol. 1, 439-510; Lawrence (University of Kansas Press \& Geological Society of America).

Muir-Wood, H. M. \& CoOper, G. A. (1960): Morphology, classification and life habits of the Productoidea (Brachiopoda). - Geological Society of America, Memoirs, 81: 447 pp.

Mundy, D. J. C. \& Brunton, C. H. (1986): Morphological Similarities in Some British Dinantian and Texas Permian Reef Brachiopods. - Compte Rendu Neuvième Congrès International de Stratigraphie et de Géologie du Carbonifère, Washington and Champaign-Urbana, 1979, 5 (Paleontology, Paleoecology, Paleogeography): 225232.

Paeckelmann, W. (1931): Die Fauna des deutschen Unterkarbons, II: Die Brachiopoden des deutschen Unterkarbons. 2. Die Productinae und Productus-ähnlichen Chonetinae. - Abhandlungen der Preussischen Geologischen Landesanstalt, Neue Folge, 136: 440 pp.

Pérez-Estaún, A., Bastida, F., Alonso, J. L., Marquínez, J., Aller, J., Álvarez Marrón, J., Marcos, A. \& Pulgar, J. A. (1988): A thin-skinned tectonics model for an arcuate fold and thrust belt: the Cantabrian Zone. - Tectonics, 7: 517-537.

Phillips, J. (1836): Illustrations of the Geology of Yorkshire; or a description of the strata and organic remains: accompanied by a geological map, sections, and diagrams, and figures of the fossils. Part II. The Mountain Limestone District. - XX+253 pp.; London (Murray).

Poletaev, V. I. (2001): New and rare species of Carboniferous Spiriferids from the Donets Basin. - Paleontological Journal, 35: 591-597. [Translation of Paleontologicheskii Zhurnal 2001 (6): 28-33].

RÁCZ, L. (1964): Carboniferous calcareous algae and their associations in the San Emiliano and Lois-Ciguera formations (Prov. León, NW Spain). - Leidse Geologische Mededelingen, 31: 1-112. 
Ramovš, A. (1971): Connections of the Upper Carboniferous brachiopod faunas from the Carnic Alps and Karavanke Mountains with those of the Cantabrian Mountains (Spain). - In: WAGner, R. H. (Ed.): The Carboniferous of Northwest Spain, 2. - Trabajos de Geología, 4: 373-377.

Reuther, C.-D. (1977): Das Namur im südlichen Kantabrischen Gebirge (Nordspanien): Krustenbewegungen und Faziesdifferenzierung im Übergang Geosynklinale Orogen. - Clausthaler Geologische Abhandlungen, 28: $122 \mathrm{pp}$.

Rodríguez, S. (1984): Corales rugosos del Carbonífero del Este de Asturias. - Tesis Doctoral, Universidad Complutense de Madrid, 109/84: 528 pp.

SÁnchez de PosAdA, L. (1976): Quelques remarques au sujet de la répartition des faunes d'Ostracodes carbonifères dans la chaîne Cantabrique. - Annales de la Société Géologique du Nord, 96: 407-412.

SÁnchez de Posada, L. C. \& García-Alcalde, J. L. (1999): Jaime Truyols. Paleontólogo, maestro y primer Presidente de la Sociedad Española de Paleontología. Revista Española de Paleontología, $N^{\circ}$ extr. Homenaje al Prof. Truyols: 5-14.

Sánchez de Posada, L. C., Martínez Chacón, M. L., MÉndez, C. A. \& Villa, E. (2001): Rasgos paleontológicos del Carbonífero marino cantábrico. - In: GÁMEZ Vintaned, J. A. \& Liñan, E. (Eds.): Memorias de las VII Jornadas Aragonesas de Paleontología. La Era Paleozoica. El desarrollo de la vida marina. Homenaje al Prof. Jaime Truyols, 191-222; Zaragoza (Institución "Fernando el Católico").

Sanz-López, J., Blanco-Ferrera, S., García-López, S. \& SÁNChez DE PosAdA, L. C. (2006): The mid-Carboniferous boundary in northern Spain: difficulties for correlation of the global stratotype section and point. Rivista Italiana di Paleontologia e Stratigrafia, 112: 3-22.

Sarytcheva, T. G. \& Sokolskaya, A. N. (1959): O klassifikatsii lozhnoporitykh brakhiopod. - Doklady Akademiya Nauk SSSR, 125: 181-184. [Translation: The classification of the pseudopunctate brachiopods. Doklady of the Academy of Sciences of the USSR, Earth Science section, 125 (1960): 348-350].

Sowerby, J. (1812-1815): The Mineral Conchology of Great Britain, vol. 1. - IV+234 pp.; London (Published by the author).

- (1821-1822): The Mineral Conchology of Great Britain, vol. 4. - 114 pp.; London (Published by the author).

StuckenberG, A. (1905): Die Fauna der Obercarbonischen Suite des Wolgadurchbruches bei Samara. - Mémoires du Comité Géologique, nouvelle série, 23: 144 pp. [In Russian with extensive German summary].

Sutherland, P. K. (1996): Ardmosteges orchanus new genus, new species, in the Early Pennsylvanian of Oklahoma - possible ancestor to the richthofenoid brachiopods. - Paleontological Society Memoirs, 46 (Journal of Paleontology, $\mathbf{7 0}$ [2, supplement]): $25 \mathrm{pp}$.
Thomas, I. (1914): The British Carboniferous Producti. I. Genera Pustula and Overtonia. - Memoirs of the Geological Survey of Great Britain, Palaeontology, 1 (4): 197-366.

ToRnQUIST, A. (1895): Das fossilführende Untercarbon am östlichen Rossbergmassiv in den Südvogesen. I. Einleitung, Beschreibung der Brachiopoden-Fauna. - Abhandlungen der geologischen Spezialkarte von ElsassLothringen, 5 (4): 379-528.

Truyols, J., Álvarez, F., Arbizu, M. A., GarcíaAlcalde, J. L., García López, S., Martínez Chacón, M. L., Méndez Bedia, I., Méndez Fernández, C. A., Menéndez, J. R., SÁnchez de Posada, L. \& Soto, F. (1984): Mapa Geológico de España, E. 1:50.000, Hoja no 104 (Boñar). - Memoria: 77 pp.; Madrid (Instituto Geológico y Minero de España).

TsCHERNYSCHEW, T. N. (1885): Der permische Kalkstein in Gouvernement Kostroma. - Verhandlungen der Russisch-Kaiserlichen Mineralogischen Gesellschaft zu St. Petersburg, 20.

Villa, E. (1982): Observaciones sobre la edad de la Formación Valdeteja (Carbonífero de la Cordillera Cantábrica) en su área-tipo. - Revista Española de Micropaleontología, 14: 63-72.

ViLlA, E. (1989): Foraminíferos Bashkirienses de la Sierra del Sueve (Cuenca Carbonífera Central, Zona Cantábrica, NW de España). - Revista Española de Paleontología, 4: 81-89.

Villa Otero, E. (1995): Fusulináceos Carboníferos del Este de Asturias ( $\mathrm{N}$ de España). - Biostratigraphie du Paléozoïque, 13: 261 pp.

Villa, E., Sanchez de Posada, L. C., Martínez Chacón, M. L. \& Stavros, C. (2001): Foraminifera and biostratigraphy of the Valdeteja Formation stratotype (Carboniferous, Cantabrian Zone, NW Spain). - Facies, 45: 59-86.

WaAgen, W. (1885): Salt Range fossils, vol. I, part 4. Productus Limestone fossils, Brachiopoda. - Memoirs of the Geological Survey of India, Palaeontologia Indica, 13 (5): 729-770.

Wagner, R. H. (1963): A general account of the Palaeozoic rocks between the Rivers Porma and Bernesga (León, NW. Spain). - Boletín del Instituto Geológico y Minero de España, 74: 170-334.

Wagner, R. H. \& Winkler Prins, C. F. (2000): Carboniferous stratigraphy of the Sierra del Brezo in northern Palencia (Cantabrian Mts, NW Spain): evidence of major uplifts. - Trabajos de Geología, 21 (for 1999: Volumen Homenaje a J. Truyols): 385-403.

Wagner, R. H., Winkler Prins, C. F. \& Riding, R. E. (1971): Lithostratigraphical units of the lower part of the Carboniferous in northern León, Spain (with a Note on some goniatite faunas by C.H.T. WAGNER-GENTIS). - In: WAGNER, R. H. (Ed.): The Carboniferous of Northwest Spain, 2. - Trabajos de Geología, 4: 603-633.

Waterhouse, J. B. (1978): Permian Brachiopoda and Mollusca from north-west Nepal. - Palaeontographica, (A), 160: 1-175.

White, C. A. (1861): Observations upon the geology and palaeontology of Burlington, Iowa, and its vicinity. Boston Journal of Natural History, 7: 209-235. 
Winkler Prins, C. F. (1968): Carboniferous Productidina and Chonetidina of the Cantabrian Mountains (NW Spain): systematics, stratigraphy and palaeoecology. Leidse Geologische Mededelingen, 43: 41-126.

- (1971): The road section East of Valdeteja with its continuation along the Arroyo de Barcaliente (Curueño River Valley, León) (with a "Note on Leonardophyllum leonense sp. nov." by G. E. DE GROOT). - In: WAGNER, R. H. (Ed.): The Carboniferous of Northwest Spain, 2. Trabajos de Geología, 4: 677-684.

- (1983): A general review of the Carboniferous brachiopods from the Cantabrian Mountains (North Spain). In: Lemos DE SousA, M. J. (Ed.): Contributions to the Carboniferous geology and palaeontology of the Iberian Peninsula, 69-91; Porto (Faculdade de Ciências, Universidade do Porto).

- (2007): The role of Spain in the development of the reef brachiopod faunas during the Carboniferous. - In: Renema, W. (Ed.): Biogeography, Time and Place: Distributions, Barriers and Islands, 217-246; Dordrecht (Kluwer \& Springer).
Wolfenden, E. B. (1958): Paleoecology of the Carboniferous reef complex and shelf limestones in northwest Derbyshire, England. - Bulletin of the Geological Society of America, 69: 871-898.

Manuscript received: April 28th, 2008.

Revised version accepted by the Stuttgart editor: September 9th, 2008.

\section{Addresses of the authors:}

Martínez Chacón, M. L., Departamento de Geología, Universidad de Oviedo, Arias de Velasco s.n.,

33005 Oviedo, Spain;

E-mail:mmchacon@geol.uniovi.es

Winkler Prins, C. F., Nationaal Natuurhistorisch Museum, P.O. box 9517, 2300 RA Leiden, The Netherlands;

e-mail: winkler@nnm.nl 